\title{
THE IMPACT OF INVESTMENT ARBITRATION ON INVESTMENT TREATY DESIGN: MYTH VERSUS REALITY
}

\author{
Wolfgang Alschner ${ }^{*}$
}

\begin{abstract}
Investor-state arbitration (ISA) has shaped the practice, scholarship and teaching of international investment law, but to what extent has it shaped its substance? According to anecdotal evidence, states change their investment treaties in response to developments in investment arbitration. To separate myth from reality this article empirically investigates the effect of investment arbitration on treaty making through three impact channels: (1) investment clauses, (2) investment claims and (3) investment case law coding close to 1700 international investment agreements (IIA) across 55 clauses. The analysis sheds new light on several normative debates within the field. First, we find that the omission or inclusion of investment clauses has no material effect on other treaty design elements. This suggests that ISA clauses are procedural add-ons, which bestow investors with enforcement rights, but do not alter the inter-state nature of the treaties' substantive obligations. Second, contrary to prior anecdotal and empirical evidence, investment claims do not lead to systematic treaty design changes. Most innovation attributed to investment claims actually pre-dates them. Moreover, only in few countries did investment claims trigger treaty design changes. Hence, rather than worrying about overzealous responses by states to "rebalance" IIAs in the face of investment claims, we should be concerned about the field's path dependency and its entrenchment in a pre-arbitration architecture. Third, investment case law exerts the strongest impact on treaty making as controversial interpretive outcomes in investment arbitration trigger traceable changes in treaty design. Hence, states are more active in fine-tuning existing commitments than in designing new ones further entrenching IIAs' path dependency and lack of innovation.
\end{abstract}

\footnotetext{
* PhD, LLB, BA, MA, JSM (Stanford). Research Fellow at the Graduate Institute of International and Development Studies, Geneva, and the World Trade Institute, Bern. I gratefully acknowledge the funding support from the SNF project "Convergence versus Divergence? Text-as-data and Network Analysis of International Economic Law Treaties and Tribunals" and from NCCR trade regulation. Email: wolfgang.alschner@graduateinstitute.ch.
} 


\section{TABLE OF CONTENTS}

\section{Introduction}

I. Investment Law and Arbitration $\quad \mathbf{7}$

A. The development of investment law and arbitration 7

B. Three impact channels 12

1. Investment arbitration clauses 12

2. Investment arbitration claims 14

3. Investment arbitration case law 16

2. Methodology 18

A. The dataset 18

B. Coding of treaty features 19

1. Codebook of treaty provisions 20

2. Representation of treaty design 20

C. Research design 21

3. The Evolution of Investment Treaty Design 21

A. Evolving investment treaty design $\quad 21$

B. Mind the gap: The crucial difference between treaty innovation and diffusion 22

C. Developments in investment arbitration $\quad 26$

4. The Impact of Arbitration Clauses on Rule Making 27

A. No material impact on treaty design $\quad 27$

1. ISA clauses and procedural safeguards 28

2. ISA clauses and substantive treaty design differences 28

B. Implications for normative debates 32

1. Procedural controls and the depoliticization of investment disputes 32

2. Substantive investor rights? ISA clauses as mere procedural add-ons 33

5. The Impact of Arbitration Claims on Rule Making 36

A. Learning from claims? 36

1. Bayesian learners $\quad 37$

2. Bounded rational learners $\quad 37$

3. Limitations of existing econometric evidence and the need for context 38

B. Treaty design innovation and investment claims 39

1. Innovation in the early 1990s: Anticipating rather than reacting to investment claims $\quad 39$

2. Innovation in the early 2000: Refinements based on case law developments $\begin{array}{ll}\text { rather than learning from claims } & 42\end{array}$

C. Treaty design diffusion and investment claims 43

1. Bi-directional causation 43

2. Stories of (non)diffusion: U.S., Canada, Germany and Japan 46

D. Conclusion: Status quo bias rather than backlash against arbitration 58

1. No backlash against investment arbitration $\quad 59$

2. Status quo bias and anchoring in a pre-ISA architecture 59

3. Transparency as pre-condition for policy change 60

6. The Impact of Arbitration Awards on Rule Making 61

A. Identifying the impact of arbitral case law 61 
B. Case studies of investment treaty changes induced by case law

1. Substantive refinements

2. Procedural innovations

C. Conclusion

72

7. Conclusion 


\section{INTRODUCTION}

Investor-state arbitration (ISA) has become the defining feature of international investment law. ISA dominates public discussions and policy debates that accompany the negotiation of new investment agreements, it forms the lens through which investment law is analyzed and taught at universities, and it has grown to be a significant area of practice for lawyers, arbitrators and legal service providers. Given its prominence, it is high time to ask just how influential ISA has been in shaping the rules that make up international investment law.

International investment law is primarily based on over three thousand international investment agreements (IIAs). ${ }^{1}$ Investment law scholars often assert that states change these treaties in response to developments in investment arbitration - although they typically disagree on whether to herald that change as a long overdue "re-balancing" of rights and obligations or as an undesirable lowering of investment protection levels. ${ }^{2}$ Apart from few exceptions, ${ }^{3}$ however, no serious effort has been made to investigate the effect of investment arbitration on IIA rule making empirically. This is problematic. In the absence of empirical knowledge, legal scholars and investment policy makers are bound to rely on potentially misleading anecdotal evidence to inform their normative evaluations and policy assessments. Few but vivid examples of states changing their IIAs in light of investment claims risk dominating the collective thinking, while crucial yet latent trends at the intersection of arbitration and treaty innovation are overlooked.

\footnotetext{
${ }^{1}$ UNCTAD, WORLD INVESTMENT REPORT 2015. REFORMING INTERNATIONAL INVESTMENT GOVERNANCE 106 (2015).

${ }^{2}$ On the rebalancing side see Kenneth J. Vandevelde, A comparison of the 2004 and 1994 US Model BITs: rebalancing investor and host country interests, in YEARBOOK ON InTERNATIONAL INVESTMENT LAW AND POLICY 2008-9 (Karl P. Sauvant ed., 2009); Anne van Aaken, International investment law between commitment and flexibility: a contract theory analysis, 12 J. INT. ECON. LAw 507-538 (2009); S. A. Spears, The Quest for Policy Space in a New Generation of International Investment Agreements, 13 J. INT. ECON. LAW 1037-1075 (2010); On the lowering standards side see Stephen M. Schwebel, The United States 2004 Model Bilateral Investment Treaty: an exercise in the regressive development of international law, in JUSTICE IN INTERNATIONAL LAW (2011); José E. Alvarez, The Return of the State, 20 MinN. J. InT. LAW 223 (2011).

3 UNCTAD, INVESTOR-STATE DISPUTE SETTLEMENT AND IMPACT ON INVESTMENT RULEMAKING (2007) assesses ISA's impact on rule making. Yet, the report focuses exclusively on the impact of case law developments rather than investigating the impact of claims as well. Conversely, Mark S. Manger \& Clint Peinhardt, Learning and Diffusion in International Investment Agreements, (2013) look at the impact of claims, but not of awards. No study comprehensively and empirically investigates ISA's effect on rule making across its various impact channels.
} 
To place the current investment law and policy discourse on a more solid empirical footing, this article systematically investigates the impact of investor-state arbitration on treaty making via three channels. First, both historically and in today's practice, not all investment treaties contain consent to investment arbitration. So what can the absence or presence of an ISA clause tell us about the design of an investment treaty more generally? Are states, for instance, more willing to agree on tough investment protection in treaties that do not provide consent to ISA, because they know that these obligations cannot be effectively enforced? Second, ISA may impact investment treaty design through claims. When a country is subject to an investment claim or learns about investment claims against other countries, it may adjust or "re-balance" its treaty design to make it easier to defend against future investment cases. Third, ISA may influence treaty design through the case law it generates. States may react to awards either by endorsing a specific interpretation by an arbitral tribunal or by explicitly rejecting it in future treaties.

This article assesses the impact of investment arbitration on rule making via these three channels by using state-of-the-art information extraction techniques. According to the United Nations Conference on Trade and Development (UNCTAD) the IIA regime has become "too big and complex to handle for governments and investors alike." ${ }^{4}$ Modern technology can help reduce that complexity opening up unprecedented avenues for large-scale empirical research. Contributing to the emerging computational analysis of the international investment regime, ${ }^{5}$ this article employs machine-coding to investigate close to 1700 bilateral investment treaties (BITs) and free trade agreements (FTAs) with investment chapters across 55 recurring investment treaty clauses. It finds (1) that the inclusion or omission of ISA has no material effect on other treaty design elements, (2) that countries do not systematically change their IIAs in the face of investment claims and (3) that developments in arbitral case law have traceable repercussions on treaty design. These insights shed light on several normative and policy debates within investment law.

First, recognizing that ISA clauses are mere procedural add-ons whose omission or inclusion has no material effect on treaty design should put us on guard not to overstate the transformative impact of investor-state arbitration. In

\footnotetext{
${ }^{4}$ UNCTAD, WORLD INVESTMENT REPORT 2011. NON-EQUiTy MODES OF INTERNATIONAL PRODUCTION AND DEVELOPMENT xvi (2011).

5 See Wolfgang Alschner \& Dmitriy Skougarevskiy, Mapping the Universe of International Investment Agreements, 19 J. INT. ECON. LAW (2016). For the corresponding website visit www.mappinginvestmenttreaties.com.
} 
particular, the empirical finding weighs against viewing the inclusion of ISA as creating substantive investor rights or as turning IIAs into the international equivalent of a contract for the benefit of a third party. The analysis rather suggests that ISA clauses merely provide an alternative procedural enforcement right for investors, but otherwise leave the inter-state nature of the treaty's substantive rights and obligations unaltered.

Second, the insight that investment claims had little impact on treaty design should prompt us to view the current IIA landscape in a new light. The "rebalancing" of rights and obligations in IIAs, long held as a product of rising investment claims, actually pre-dates the surge of claims and can be traced back to NAFTA. The subsequent diffusion of NAFTA design elements is due to a multiplicity of factors among which is NAFTA itself. By inspiring the first wave of investment claims, NAFTA became entrenched as template for future treaty making in a path dependent IIA universe. Investment claims also played a part in helping to diffuse NAFTA treaty design, but with varying degrees of importance: while the U.S. learned from NAFTA claims transposing its design to BITs, other countries like Canada, Germany or Japan experienced no equivalent effect. As their case studies show, bureaucratic inertia, public awareness of ISA and the interaction of investment and trade law were often more important than claims in shaping treaty design outcomes. This insight is both good and bad in legal policy terms. It is good because states have not reacted to rising ISA claims by opportunistically altering their treaty design to escape liability. But it is also bad because our findings point to a status quo bias in treaty making. While states have thus not overreacted to investment claims, as some commentators feared, they may have actually done too little in response to a changing policy environment entrenching a pre-ISA claims architecture rather than engaging in genuine innovation.

Finally, the finding that states systematically react to arbitral case law points to the type of legal innovation that states do engage in. They fine-tune existing treaty commitments in light of legal developments, investing in the gradual adjustment of the field rather than reinventing it. Hence, as arbitral case law with quasi-precedential effect spreads, states take on an active role intervening in ongoing normative debates that play out in arbitration by changing their treaty design endorsing or rejecting a strand of arbitral interpretations.

The study thus reveals that investment arbitration's impact on rule making is surprisingly small and that other factors, including a status quo bias and path dependency, are more important determinants of (and obstacles to) treaty design innovation and diffusion. The article proceeds in three stages. The first 
introduces investment treaties and arbitration and identifies the three channels by which the former may impact the latter drawing from the existing literature. The second lays out the empirical methodology for measuring the impact of ISA on treaty design. The third then applies that methodology to investment law tracing the evolution of IIAs generally before then isolating the influence of the three impact channels clauses, claims and cases on treaty design.

\section{INVESTMENT LAW AND ARBITRATION}

International investment law has become one of the most dynamic, but also most controversial fields of international law. This section briefly traces the development of investment law and its investor-state arbitration component and then identifies the three channels by which arbitration may have impacted international investment treaty making.

\section{A. The development of investment law and arbitration}

Historically, investment law developed from the customary international law protection of foreign nationals abroad. In the $19^{\text {th }}$ century, European states and the U.S. argued that aliens were entitled to a minimum standard of protection under international law. ${ }^{6}$ This minimum standard was initially hotly contested by newly independent states in Southern America - in part because it often served as pretense to justify foreign military interventions ("gunboat diplomacy"). ${ }^{7}$ By the early $20^{\text {th }}$ century, however, as inter-state arbitrations began to gradually replace the use of force as primary means to enforce the protection of foreign nationals, including investors, abroad, the minimum standard gained credence and became a part of customary international law. ${ }^{8}$

Contestation over the protection of foreign investors began anew in the second half of the $20^{\text {th }}$ century. ${ }^{9}$ Decolonization and socialism placed emphasis on

${ }^{6}$ Jonathan Gimblett \& O.Thomas Johnson, Jr., From Gunboats to BITs: The Evolution of modern International Investment Law, in YEARBOOK ON INTERNATIONAL INVESTMENT LAW \& POLICY VOL. 2010-2011 , 650-657 (Karl P. Sauvant ed., 2011).

${ }^{7}$ Santiago Montt, State Liability in Investment Treaty Arbitration: Global CONSTITUTIONAL AND ADMINISTRATIVE LAW IN THE BIT GENERATION 1 (2009).

${ }^{8}$ The most famous decision in this context is the 1926 Neer case (L.F.H. Neer and Pauline Neer (U.S.A.) v. United Mexican States, 15 October 1926, Reports of International Arbitral Awards, Vol. IV, p. 60-66. (1946)), which continues to be widely cited by investment tribunals to describe the content of the international minimum standard. On the minimum standard, see generally MARTINS PAPARINSKIS, THE INTERNATIONAL MINIMUM STANDARD AND FAIR AND EQUITABLE TREATMENT (2013).

9 Kenneth J. Vandevelde, Bilateral Investment Treaties: History, Policy, and 
sovereign control over natural resources, which often conflicted with existing foreign ownership rights. ${ }^{10}$ The ensuing waves of expropriation combined with a series of United Nations resolutions on a "New International Economic Order" challenged the customary rules on the protection of aliens including the level of compensation owed to foreign investors in case of an expropriation. ${ }^{11}$ Developed countries responded in two ways to this contestation. First, they began codifying the protection of foreign investors by signing bilateral investment treaties (BITs) with like-minded developing countries. ${ }^{12}$ Second, they promoted the establishment of an international arbitration mechanism that would depoliticize foreign investment relations by allowing private investors to bring their claims directly against host states before international arbitration tribunals. ${ }^{13}$ The latter efforts culminated in the conclusion of the Convention on the Settlement of Investment Disputes between States and Nationals of Other States (ICSID) in 1965 under the auspices of the World Bank. ${ }^{14}$

Following the end of the Cold War, contestation gave way to a global acceptance of investment protection and arbitration. ${ }^{15}$ Today virtually every country is signatory to at least one of the around 3000 bilateral investment treaties (BITs) and several hundred free trade agreements (FTAs) with investment chapters that have been signed since the 1960s. ${ }^{16}$ Most of these agreements provide consent to investor-state arbitration, be it under ICSID or

INTERPRETATION 48 (2010); M. SORNARAJAH, THE INTERNATIONAL LAW ON FOREIGN INVESTMENT (3rd ed. 2010); S. P SUBEDI, 67 INTERNATIONAL INVESTMENT LAW: RECONCILING POLICY AND PRINCIPLE 67 (2008).

${ }^{10}$ Gimblett and Johnson, Jr., supra note 7 at 669-681.

${ }^{11}$ UN General Assembly, Charter of Economic Rights and Duties of States, Resolution 3281 (XXIX), UN Doc. A/RES/3281(XXIX) (adopted 12 December 1974), Article 2(2)c). UN General Assembly, Permanent Sovereignty over Natural Resources, UN Doc. A/RES/1803 (XVII) (adopted 14 December 1962). UN General Assembly, Declaration on the Establishment of a New International Economic Order, UN Doc. A/RES/S$6 / 3201$.

${ }^{12}$ Kenneth J. Vandevelde, Brief History of International Investment Agreements, A, 12 UC DAVIS J INTL Pol 157, 168 (2005); Jeswald W. Salacuse, Treatification of International Investment Law, The, 13 LAW BUS REV AM 155, 156 (2007).

13 Aron Broches, Selected Essays: World Bank, ICsid, AND Other Subjects of Public AND PRIVATE InTERnATIONAL LAW 163 (1995); Ibrahim F. I. Shihata, Toward a Greater Depoliticization of Investment Disputes: The Roles of ICSID and MIGA, in Investing With CONFIDENCE: Understanding Political Risk MANAGEMENT IN THE 21st Century 2-35 (Kevin W. Lu, Gero Verheyen, \& Srilal Mohan Perera eds., 2009); See generally ANTONIO R. PARRA, THE HiSTORY OF ICSID (2012).

14 International Centre for Settlement of Investment Disputes (ICSID), created by 1965 Convention on the Settlement of Investment Disputes Between States and Nationals of Other States, 17 UST 1270, TIAS 6090, 575 UNTS 159.

${ }^{15}$ Vandevelde, supra note 13 at $175-177$.

${ }^{16}$ UNCTAD, supra note 2 at 106. 
another forum. ${ }^{17}$ Treaty-based ISA, however, lay largely dormant until the mid 1990s. Since then, investors have brought over 600 cases pursuant to investment treaties. ${ }^{18}$ If successful, the respondent state is liable to pay damages. ${ }^{19}$ Such damage awards benefit from the strong recognition and enforcement infrastructure of the ICSID Convention (for ICSID awards) and the 1958 New York Convention (for non-ICSID awards) and can thus effectively attach host state assets around the world not protected by sovereign immunity. $^{20}$

Through its effectiveness, investment arbitration has become a cornerstone of today's investment law architecture and has transformed the way we think about the field. Investment law scholars today spend most of their time making sense of arbitral case law rather than interpreting investment treaties, contracts or domestic law. Similarly, university courses are taught on "investment arbitration" rather than "investment law" to prepare students for an increasingly litigation-focused area of practice. While ISA makes investment law attractive for scholars and practitioners, it also makes investment law controversial. Some investment arbitration claims have challenged sensitive areas of public policy making giving rise to fears that investment treaties and arbitration could compromise the state's ability to regulate in the public interest leading to "regulatory chill". ${ }^{21}$ Furthermore, the ad hoc structure of

17 Jason Webb Yackee, Conceptual Difficulties in the Empirical Study of Bilateral Investment Treaties, 33 BROOKLYN J. INT. LAW 405, 423-429 (2007).

18 UNCTAD, WORLD INVESTMENT REPORT 2014. INVESTING IN THE SDGS: AN ACTION PLAN 124 (2014).

19 Alan O. Sykes, Public versus Private Enforcement of International Economic Law: Standing and Remedy, 34 J. LEG. STUD. 631-666 (2005); IRMGARD MARBOE, CALCULATION OF COMPENSATION AND DAMAGES IN INTERNATIONAL INVESTMENT LAW (2009); Wolfgang Alschner, Aligning Loss and Liability - Towards an Integrated Assessment of Damages in Investment Arbitration, in THE USE OF ECONOMICS IN InTERnAtional TRADE Disputes: LESSONS LEARNED AND Challenges AHEAD (Theresa Carpenter, Marion Jansen, \& Joost Pauwelyn eds., forthcoming), http://papers.ssrn.com/abstract=2569426 (last visited May 9, 2015).

${ }^{20}$ RUDOLF DOLZER \& CHRISTOPH SCHREUER, PRINCIPLES OF INTERNATIONAL INVESTMENT LAW 310-312 (2nd ed ed. 2012).

${ }^{21}$ See e.g. Stephan W. Schill, Do Investment Treaties Chill Unilateral State Regulation to Mitigate Climate Change?, 24 J. INT. ARBITR. (2007); Tienhaara Kyla, Regulatory Chill and the Threat of Arbitration: A View from Political Science, in EvOLUTION IN InVESTMENT TREATY LAW AND ARBITRATION 606-628 (Chester Brown \& Kate Miles eds., 2011). The perhaps most notorious cases against public interest regulations involve Phillip Morris' legal actions to impede tobacco control legislation. See Philip Morris Brand Sarl (Switzerland), Philip Morris Products S.A. (Switzerland) and Abal Hermanos S.A. (Uruguay) v. Oriental Republic of Uruguay, ICSID Case No. ARB/10/7; Philip Morris Asia Limited v. The Commonwealth of Australia, UNCITRAL, PCA Case No. 2012-12. 
arbitration modeled on commercial arbitration, its (partial) secrecy and the relatively small pool of practitioners with revolving roles as negotiators, arbitrators and counsels have attracted academic and public criticism. ${ }^{22}$ ISA has thereby become a publicly debated and contested element of investment law.

Given its prominence among proponents and critics, the question arises just how much of today's investment law is owed to investor-state arbitration? While it is beyond doubt that ISA has revolutionized the litigation of investment disputes, it is much less clear to what extent it has also changed the substance of IIAs that form the underpinning of today's investment law architecture.

Prominent commentators have argued that investment arbitration has transformed the substantive nature of IIAs. Thomas Wälde, for instance, suggested that the inclusion of ISA "fundamentally changed the character of BITs."23 Similarly, Michael Reisman stated that ISA turned BITs into "contracts for the benefit of third parties." 24 Pauwelyn argues that ISA "fundamentally transformed the rules on foreign investment protection" 25 and introduces a distinction between generations of BITs depending on whether consent to ISA is included. ${ }^{26}$ For Spierman, the insertion of ISA into modern BITs even "vest[s] rights in private investors as subjects of international law." ${ }^{, 27}$ More than just creating another enforcement route, ISA, according to them, thus seems to have altered the substance of international investment law.

In addition, there is widespread agreement in the literature that ISA has

\footnotetext{
${ }^{22}$ Corporate Europe ObServatory and Transnational Institute, Profiting from INJUSTICE: HOW LAW FIRMS, ARBITRATORS AND FINANCIERS ARE FUELLING AN INVESTMENT ARBITRATION BOOM, Brussels (2012), available at: www.tni.org/files/download/profitingfrominjustice.pdf

GUS VAN HARTEN, INVESTMENT TREATY ARBITRATION AND PUBLIC LAW (2007).

${ }^{23}$ Thomas W Wälde, Interpreting Investment Treaties: Experiences and Examples, in INTERNATIONAL INVESTMENT LAW FOR THE 21ST CENTURY: ESSAYS IN HONOUR OF CHRISTOPH SCHREUER 724-781, 748 (Christina Binder et al. ed., 2009).

${ }^{24}$ Republic of Ecuador v. United States of America, PCA Case No. 2012-5, Expert Opinion with Respect to Jurisdiction, Prof. W. Michael Reisman (Apr. 24, 2012) 93.

${ }^{25}$ Joost Pauwelyn, At The Edge of Chaos: Foreign Investment Law As A Complex Adaptive System, How It Emerged and How It Can Be Reformed, 29 ICSID Rev. 372-418, 395-6 (2014).

${ }^{26}$ Pauwelyn, supra note 26; See also Yackee, supra note 18; Axel Berger et al., More Stringent BITs, Less Ambiguous Effects on FDI? Not a Bit!, KIEL InST. WORLD ECON. KIEL WORK. PAP. (2010).

${ }^{27}$ O. Spiermann, Twentieth Century Internationalism in Law, 18 EuR. J. INT. LAW 785814,811 (2007).
} 
triggered a major overhaul of IIAs across the globe over the past decade. The proliferation of ISA claims is said to have created a "backlash against investment arbitration" 28 and, according to UNCTAD, "led to the emergence of 'new generation' IIAs." 29 This "new generation" places greater emphasis on host state policy flexibility and non-investment values than earlier agreements. ${ }^{30}$ The evidence for widespread treaty design reform in response to the proliferation of investment claims is largely anecdotal, however. Commentators routinely invoke the United States' experience pointing to the stark differences between the pre-arbitration-claims 1994 U.S. model BIT and the post-arbitration-claims 2004 model BIT in making the case for a strong impact of arbitration on rule-making. ${ }^{31}$ Scholars thereby risk jumping from correlation to causation attributing treaty design innovations that co-occur with the proliferation of investment claims to the latter. ${ }^{32}$ Furthermore, it is unclear how representative the U.S. case is for developments in the wider IIA universe. While a major reform of IIAs seems under way with EU proposing a new investment court system ${ }^{33}$ and countries such as India revamping their model BITs, ${ }^{34}$ at the time of writing these more far-reaching changes remain yet to be implemented. Widespread talk of reform thus tends to detract from investigations into how much concluded agreements have changed in fact since the rise of investment arbitration. A case in point is the investment

28 The Backlash Against Investment Arbitration: Perceptions and Reality, (Michael Waibel ed., 2010).

${ }^{29}$ UNCTAD, WORLD INVESTMENT RePORT 2013. GLOBAL VAlue Chains: INVESTMENT AND TRADE FOR DEVELOPMENT 107 (2013); similarly, Manger and Peinhardt, supra note 4 at 3 ("many states have begun to rethink their investment treaty commitments after appearing before international tribunals").

30 UNCTAD, World InVESTMEnt Report 2012. TOWARds a New Generation of INVESTMENT POLICIES 101-2 (2012); Spears, supra note 3.

${ }^{31}$ Manger and Peinhardt, supra note 4 at 3; Vandevelde, supra note 3; Kenneth J. Vandevelde, Model Bilateral Investment Treaties: The Way Forward, 18 Sw J InTL L 307 (2011); Schwebel, supra note 3.

${ }^{32}$ R. Echandi, A New Generation of International Investment Agreements in the Americas: Impact of Investor-State Dispute Settlement over Investment Rule-Making, in FOURTH ANNUAL CONFERENCE OFTHE EURO-LATIN STUdy NETWORK ON INTEGRATION AND TRADE (ELSNIT) (2006) (listing innovations following ISA claims without systematically investigating their origins); Similarly, UNCTAD, supra note 4.

33 European Commission, EU Finalises Proposal for Investment Protection and Court System for TTIP, Press Release (12 November 2015) < http://europa.eu/rapid/pressrelease IP-15-6059 en.htm> accessed 10 December 2015. Other authors have made similar proposals, see e.g. Gus Van Harten, A Case for an International Investment Court, INAUG. CONF. SOC. InT. ECON. LAW (2008), http://digitalcommons.osgoode.yorku.ca/all_papers/259.

${ }^{34}$ Ashutosh Ray, Unveiled: Indian Model BIT, Kluwer Arbitration Blog (Jan 18, 2016), available at: http://kluwerarbitrationblog.com/2016/01/18/unveiled-indian-model-bit/ (last visited Aug. 15, 2016). 
chapter of the Transpacific Partnership (TPP) Agreement, which has been advertised as a "new, gold standard", yet to $81 \%$ it simply reproduces the language of a prior 2006 U.S. agreement and contains few genuine innovations. ${ }^{35}$ In short, ISA is often perceived as transformative of IIAs. But we actually do not know how transformative has it really been.

\section{B. Three impact channels}

This article empirically investigates ISA's impact on investment treaty making in order to answer that question. More specifically, it focuses on three channels through which ISA could have affected the design of international investment agreements: (1) investment arbitration clauses, (2) investment arbitration claims and (3) investment arbitration case law.

\section{Investment arbitration clauses}

The first way by which ISA may have impacted IIA design is through its mere inclusion. Before the late 1960s, the enforcement of international investment law was exclusively an inter-state business. ${ }^{36}$ The law of diplomatic protection as part of customary international law translated injuries against foreign nationals into injuries against their home state turning investorstate disputes into inter-state disputes. ${ }^{37}$ Concordantly, early investment treaties provided exclusively for state-to-state dispute settlement clauses. ${ }^{38}$ The situation changed dramatically in the 1960s when the ICSID Convention was signed and IIAs, starting with the Netherlands-Indonesia BIT (1968), began to

${ }^{35}$ Wolfgang Alschner \& Dmitriy Skougarevskiy, The New Gold Standard? Empirically Situating the Trans-Pacific Partnership in the Investment Treaty Universe, 17 J. WORLD InVEST. TRADE (2016). See also Lisa Sachs \& Lise Johnson, The TPP's Investment Chapter: Entrenching, Rather Than Reforming, a Flawed System, CCSI Policy Paper, November 2015 available at: http://ccsi.columbia.edu/files/2015/11/TPP-entrenchingflaws-21-Nov-FINAL.pdf (last visited Aug. 21, 2016).

36 Wolfgang Alschner, The Return of the Home State and the Rise of "Embedded" Investor-State Arbitration, in THE ROLE OF THE STATE IN INVESTOR-STATE ARBITRATION 293-333, 298-299 (2015).

${ }^{37}$ In the 1960s, Belgium, for instance, brought a diplomatic protection claim on behalf Belgian investors against Spain before the International Court of Justice alleging that Spain's acts vis-à-vis an electricity provider, which had a majority ownership of Belgian shareholders, violated international law. Barcelona Traction, Light and Power Company, Limited (Belgium v. Spain), 1970 ICJ Reports 3, Judgment (Feb. 5, 1970) ๆף 45-6, 54. See generally EDWIN MONTEFIORE BORCHARD, THE DIPLOMATIC PROTECTION OF CITIZENS ABROAD: OR, THE LAW OF INTERNATIONAL CLAIMS (1915).

${ }^{38}$ American Friendship Commerce and Navigation (FCN) Treaties and early European BITs delegated the settlement of investment disputes either to the International Court of Justice or to ad-hoc inter-state arbitration. 
include consent to its jurisdiction or to alternative investor-state arbitration mechanisms. ${ }^{39}$ By allowing private investors to directly sue host states for treaty violations, ISA stripped away the political and diplomatic considerations that had hitherto prevented many investor-state disputes from rising to the level of inter-state disputes making the enforcement of treaty violations and the ensuing payment of damages more credible and more likely.

The decision to create treaty-based ISA in the 1960s is nothing short of astonishing. During the 1960s even in deep integration projects such as the European Community (EC) states were reluctant to provide individuals with a direct means of supra-national law enforcement. It took the European Court of Justice's judgments to find a direct effect of EC law implied in the original EC treaty. ${ }^{40}$ Indeed, also by today's standards, investment law's innovation in the 1960s seems remarkable, given that compulsory adjudication of international law - let alone compulsory adjudication initiated by private parties as opposed to states - continues to be the exception rather than the rule. One thus has to wonder whether the quite radical innovation to create such a powerful and innovative enforcement mechanism was accompanied by an equally radical innovation in treaty design more generally.

Among the various ways in which ISA clauses could have affected treaty design let us just spell out two. On the substantive side, ISA clauses could have led to a lowering of investment protection levels: while states may have been ready to tie their hands to tough commitments when they knew that they are unlikely to be enforced - few inter-state investment disputes have ever been brought - they may have been more cautious if they expected to be actually held to these standards. Hence, following this line of thought, one would expect to observe either a decrease in the number of obligations or an increase of the number of exceptions in IIAs with ISA as compared to IIAs without ISA.

On the procedural side, one could expect that if states consented to the radical step of being sued by private actors before an international compulsory

\footnotetext{
${ }^{39}$ Pauwelyn, supra note 26 at 395-397.

${ }^{40}$ In its 1963 seminal judgment Van Gend en Loos, the ECJ found that a direct effect of EC Law was implied in the European Economic Community (EEC) Treaty. Van Gend en Loos v Nederlandse Administratie der Belastingen (1963) Case 26/62. As Craig and Burca explain " $[t]$ he strong intervention made on behalf of three governments. Half of the existing Member States, indicated that the concept of direct effect, understood as the immediate enforceability by individual applicants of those provisions in national courts, probably did not accord with the understanding of those states of the obligations they assumed when they created the EEC." PAUl CRAIG \& GRÁINNE DE BÚRCA, EU LAW: TEXT, CASES, AND MATERIALS 185 (2011).
} 
arbitration mechanism issuing binding monetary awards, they would also add procedural safeguards to mitigate the sovereignty impact of this choice. In the WTO context, for instance, the gradual progression from a diplomatic to a more judicial dispute settlement architecture was accompanied by a simultaneous infusion of more politics into the GATT/WTO machinery. According to Joost Pauwelyn, "more discipline and harder law (less exit) lead to and require more politics and higher levels of participation (more voice).",41 The WTO rules governing amicable settlements are an example of this bidirectional interaction of law and politics: as legalization increased, the references to disputing parties' freedom to avoid formal dispute settlement and to resolve the matter bilaterally increased as well to the point that in today's quasi-automatic and highly judicial WTO dispute settlement system a "solution mutually acceptable to the parties to a dispute and consistent with the covered agreements is clearly to be preferred." 42 Applied to the investment law context, we should expect similar procedural safeguards to accompany the inclusion of ISA in order to ensure that the contracting states have some voice and scope for politics in an otherwise highly legalized architecture. Ex ante controls embedding contracting states' preferences could carefully circumscribe the arbitration procedure. Ex post controls would allow the contracting states or other outside interests to monitor and weigh in on the tribunal's interpretation or analysis in ongoing disputes. If anything, giving private actors a direct cause of action seems to warrant an even stronger role of such elements than in the inter-state WTO context. Hence, it is reasonable to expect that ISA may have had an impact both on the substantive and the procedural content of investment treaties.

\section{Investment arbitration claims}

A second way by which ISA may have impacted IIA design is through investment claims. ISA clauses lay largely dormant for over 20 years. It was only in 1987 that an investor for the first time relied on state consent given in an investment treaty to initiate an ISA claim in AAPL $v$ Sri Lanka. ${ }^{43}$ It then took another 15 years before ISA became a more frequent means of recourse with more than 25 cases filed by year starting in $2002 .{ }^{44}$ Given this large gap before the law in the books turned into law in action, investment claims could

${ }^{41}$ Joost Pauwelyn, The Transformation of World Trade, 104 Mich. LAW REV. 1-65, 5 (2005). (Emphasis in the original)

${ }^{42}$ Article 3.7 DSU. See Wolfgang Alschner, Amicable Settlements of WTO Disputes: Bilateral Solutions in a Multilateral System., 13 WORLD TRADE REV. 65-102 (2014).

${ }^{43}$ Asian Agricultural Products Ltd. (AAPL) v. Republic of Sri Lanka, ICSID Case No. $\mathrm{ARB} / 87 / 3$.

44 See UNCTAD database on investor-state disputes, available at http://investmentpolicyhub.unctad.org/ISDS. 
constitute a second impact channel on treaty design separate from investment clauses.

Considering claims as unique impact channels finds supports in the literature. Several scholars have argued that states had not fully grasped the liability implications of ISA clauses when they were first introduced and only understood their full potential when ISA claims began to proliferate. Lauge Poulsen's empirical research on BIT diffusion convincingly shows that developing countries systematically underestimated the costs of IIAs and overestimated their benefits taking BITs for simple "photo-opportunities" and mere "ink on paper". ${ }^{45}$ Similarly, Professor Christoph Schreuer stated in an expert opinion that developing countries often "had no idea that [BITs] would have real consequences in the real world." $" 46$ In addition, commentators have also suggested that prior to the first investment claims, even developed countries could not have understood the full potential of ISA. Pauwelyn has argued that the idea of "arbitration without privity" 47 that today allows an investor to perfect an arbitration agreement with the host state by simply accepting an offer of consent unilaterally given by the host state in the investment treaty was a largely unanticipated, and initially controversial, legal innovation first accepted by the AAPL v Sri Lanka tribunal in $1990 .{ }^{48}$ Hence if both developing and developed countries were surprised by investment claims, we could expect that they altered their treaty design in response to mitigate the impact of ISA on state sovereignty.

There is a rich literature, albeit rarely empirical in nature, which addresses countries' efforts to "re-balance" investment treaties in response to investment claims - sometimes framed as a "backlash against arbitration". 49 The common theme of this literature is that investment claims exposed a substantive tension between investment protection obligations and states' regulatory powers as well as procedural shortcomings in the arbitral process such as a lack of public participation. ${ }^{50}$ In response, it is argued, states have included public policy

\footnotetext{
${ }^{45}$ Lauge N. SkovgaARd Poulsen, Bounded Rationality And ECONOMiC Diplomacy: The Politics of Investment Treaties in Developing Countries (2015); Lauge Poulsen, The Politics of South-South Bilateral Investment Treaties, in THE POLITICS OF International ECONOMic LAw (T. Broude, M.L. Busch, \& A. Porges eds., 2011); Lauge Poulsen, Bounded Rationality and the Diffusion of Modern Investment Treaties, INT. STUD. Q. (2013).

46 Expert testimony of Prof. Christoph Schreuer, Wintershall Aktiengesellschaft $v$. Argentine Republic, ICSID, Case No. ARB/04/14, Final Award (Dec. 8, 2008) ๆ 85.

${ }^{47}$ Jan Paulsson, Arbitration Without Privity, 10 ICSID REV. 232-232 (1995).

${ }^{48}$ Pauwelyn, supra note 26 at 400.

${ }^{49}$ See supra note 2. THE BACKLASH AgAinst InVESTMENT ARBITRATION, supra note 29.

${ }^{50}$ See supra note 2.
} 
exceptions into their investment treaties and refined the investment arbitration architecture to curb arbitral discretion and to allow for more involvement of outside interests. ${ }^{51}$ Following this literature, it is reasonable to expect states to have reacted to investment claims by adapting their treaty design adding policy exceptions and procedural safeguards.

\section{Investment arbitration case law}

A final way by which ISA may have impacted IIA design is through the case law it generates. As a corollary of their adjudicative functions, investment tribunals have to interpret the often vaguely phrased provisions in investment treaties. Through such interpretation they exercise a de facto law-making role filling the normative gaps left open by the treaty drafters. ${ }^{52}$ While delegation of interpretive power to tribunals saves negotiation costs ex ante, it can lead to costs ex post as third party interpreters get it wrong arriving at an interpretation unintended by the contracting parties. ${ }^{53}$ These costs of delegation are especially great if pronouncements by third party adjudicators have de facto law making power. Although there is no formal rule of precedent in investment law, parties and tribunals abundantly refer to prior arbitral interpretations in subsequent cases including but not limited to disputes involving the same treaty. ${ }^{54}$ This practice has thus given rise to a sort of "investment common law" - a body of investment case law that is widely used to elucidate the meaning of core IIA provisions across treaties. ${ }^{55}$

The existence of a parallel judge-made rule making process may impact

${ }^{51} \mathrm{Id}$.

${ }^{52}$ Rather than investing time and effort at the negotiation stage to anticipate future states of the world, states are often better off to delegate normative gap-filling to third party adjudicators. This is a basic insight of contract theory applied to treaties. See e.g. SIMON A. B. SCHROPP, TRADE POLICY FLEXIBILITY AND ENFORCEMENT IN THE WORLD TRADE ORGANIZATION: A LAW AND ECONOMICS ANALYSIS 96-98 (2009).

${ }^{53}$ UNCTAD, Interpretation of IIAs: What States can do, UNCTAD IIA ISSUE NOTE (2011); WolfGANG AlSCHNER, INTERPRETING INVESTMENT TREATIES AS INCOMPLETE CONTRACTS: LESSONS FROM CONTRACT THEORY (2013), http://papers.ssrn.com/abstract=2241652 (last visited Aug 2, 2013); Anne van Aaken, Delegating Interpretative Authority in Investment Treaties: The Case of Joint Commissions, 11 TRANSNATL. DisPUTE MANAG. TDM (2014), http://www.transnationaldispute-management.com/article.asp?key=2045 (last visited Apr 2, 2014).

${ }^{54}$ O. K. Fauchald, The Legal Reasoning of ICSID Tribunals - An Empirical Analysis, 19 EUR. J. INT. LAW 301-364 (2008).

55 M.C. Porterfield, International Common Law of Investors Rights, An, 27 U PA J INTL ECON L 79 (2006); Florian Grisel, The Sources of Foreign Investment Law, in THE FOUNDATIONS OF INTERNATIONAL INVESTMENT LAW: BRINGING THEORY INTO PRACTICE 213-233, 223-233 (Zachary Douglas, Joost Pauwelyn, \& Jorge E. Viñuales eds., 2014). 
how states as primary law makers design their treaties. Where they disagree with arbitral interpretations, states can use their normative powers to explicitly contract out of arbitral case law. ${ }^{56}$ Although states are unlikely react to all arbitral pronouncements, they are likely to take sides in controversial debates that arise in case law and that critically affect the reading of their agreements. On rare occasions, for example, states have issued binding interpretations of existing treaties: a well-known example is the interpretive note of the NAFTA parties on the meaning of NAFTA Article 1105, the minimum standard of treatment. ${ }^{57}$ More often, however, arbitral interpretations may be factored in when new agreements are negotiated. ${ }^{58}$

Aside from contracting out of arbitral case law, states can also explicitly endorse an arbitral interpretation. Where arbitrators resolve a difficult issue not anticipated by the drafters, their interpretation may serve as template in future treaty making. In a seminal piece, Thomas Schelling showed that so called "focal points" incentivize players to choose one outcome over another in coordination games involving several possible equilibria. ${ }^{59}$ In negotiations over new treaties, prior jurisprudence can constitute such a focal point leading to a convergence of views and corresponding changes in treaty design. Garrett and Weingast, for instance, use Schelling's framework to explain why the European Community member states chose the European Court of Justice's jurisprudence as template for designing its single market rules rather than devising new rules from scratch. ${ }^{60}$ In the same vein, contracting states to investment treaties may opt into solutions devised in prior arbitral case law to solve problems not explicitly addressed in their earlier treaties. With states endorsing or rejecting arbitral interpretations, investment case law may constitute a third channel by which ISA impacts the design of IIAs.

\footnotetext{
${ }^{56}$ Anthea Roberts, Power and persuasion in investment treaty interpretation, 104 AM. J. INT. LAW 179-225 (2010); UNCTAD, supra note 54.

${ }^{57}$ The NAFTA Free Trade Commission, Notes of Interpretation of Certain Chapter 11 Provisions, 31 July 2001. The decision has attracted rich and critical commentary, see e.g. Charles H. II Brower, Why the FTC Notes of Interpretation Constitute a Partial Amendment of NAFTA Article 1105, 46 VA. J. INT. LAW 347 (2005); Gabrielle Kaufmann-Kohler, Interpretive powers of the free trade commission and the rule of law, FIFTEEN YEARS NAFTA 175-194 (2011).

${ }^{58}$ The NAFTA Free Trade Commission, Notes of Interpretation of Certain Chapter 11 Provisions, for instance, was integrated into subsequent BITs including by the United States, Canada and Mexico. See e.g. Article 5 and its Annex of the 2004 U.S. Model BIT or Mexico-Czech Republic BIT (2002), Ad Article 2.

${ }^{59}$ ThOMAS C. SCHELling, THE STRATEGY OF CONFLICT 2 (1980).

${ }^{60}$ Geoffrey Garrett \& Barry R. Weingast, Ideas, Interests, and Institutions: Constructing the European Community's Internal Market, in IdEAS AND Foreign Policy: BeliefS, Institutions, AND Political Change 173-206 (Robert O. Keohane \& Judith Goldstein eds., 1993).
} 


\section{Methodology}

Using state-of-the-art empirical tools, we can trace and measure the impact of investment arbitration on treaty design through these three channels. This section presents the dataset of treaties investigated, explains the content analysis tools used to extract legally relevant information from these texts and introduces the methods for analyzing ISA's impact on treaty design.

\section{A. The dataset}

To trace change in treaty content, this paper relies on the Alschner/Skougarevskiy (2015) dataset, which is the most comprehensive collection of English-language BIT full texts to date. ${ }^{61}$ It comprises 1628 English-language BITs collected from the Kluwer Arbitration, Investment Claims and UNCTAD investment policy hub websites amounting to $51 \%$ of the entire universe of signed BITs. ${ }^{62}$ The dataset spans from 1959 (GermanyPakistan BIT) to 2014 and covers 171 countries. In spite of its breadth, the dataset under-samples two groups of signatories. First, it only captures a comparatively small portion of BITs signed by low-income countries, which, in part, is due to the fact that these countries publish their BIT full texts less frequently than higher income countries. Second, the majority of France's BITs are not included in the dataset, since it comprises English language treaties only.

Even though the sample is not fully representative of the entire population of BITs, there are three reasons why this subset of treaties still allows us to make persuasive inferences on the entire BIT population. First, although it only contains English BITs, many non-English-speaking countries negotiate English language treaties or agree on an equally authentic English text in addition to a version in their native language. Often, the English version even trumps the native language version in case of an inconsistency. ${ }^{63}$ Second, BITs are highly homogenous texts, which closely follow common model treaties and multilateral draft conventions such as the OECD Draft Convention on the

\footnotetext{
${ }^{61}$ Alschner and Skougarevskiy, supra note 6.

${ }^{62} \mathrm{Id}$.

${ }^{63}$ For instance, the BIT between Ukraine and Croatia (1993) provides in its final Article that "If there is any divergence in interpretation, the English version shall prevail." Similar formulations can be found e.g. in the Switzerland-Jordan BIT (2001) or TurkeyIran BIT (1996).
} 
Protection of Foreign Property. ${ }^{64}$ These common roots make it less likely that BITs outside our sample are substantially different from those within it. Third, even though there may be a selection bias in reporting with some countries publishing the full texts of all their treaties, while others do not, this bias is mitigated by the bilateral nature of the treaties - BITs from virtually every country are in our dataset. Taken together these three factors make it less likely that the unreported or foreign language texts contain treaty features not also present in our sample.

Supplementing the 1628 BITs, this paper also includes 52 free trade agreements (FTAs) with investment chapters such as NAFTA identified from the WTO list of regional trade agreements ${ }^{65}$ and 6 plurilateral investment agreements such as the ASEAN Comprehensive Investment Agreement identified through UNCTAD's other IIA list. ${ }^{66}$ Not included are agreements that are not substantively equivalent to BITs e.g. FTAs that do not contain both relative (e.g. national treatment) and absolute (e.g. expropriation) investment protection clauses, and subject-specific investment agreements such as the Energy Charter. In total, our dataset thus comprises close to 1700 IIAs.

Finally, data on treaty-based investment claims is taken from UNCTAD's investor-state dispute settlement (ISDS) database. ${ }^{67}$ At the time of writing, the database comprised 561 cases spanning from 1987 to 2013.

\section{B. Coding of treaty features}

To track the changing legal content of IIAs in our database the article relies an automated content analysis using machine-coding based a dictionary of treaty provisions.

\footnotetext{
${ }^{64}$ Stephan W. Schill, The Multilateralization of InTERnational InVESTMENT LaW 39-40 (2009).

${ }^{65}$ Available at http://rtais.wto.org/UI/PublicMaintainRTAHome.aspx (visited 12 May 2014). The database only lists regional trade agreements notified to the WTO.

${ }^{66}$ UNCTAD uses the label "Other IIAs" to collect various types of agreements including investment framework agreements (e.g. Chile-India Framework Agreement (2005)), treaties with limited investment-related provisions (e.g. EFTA-Peru FTA (2010) Chapter 5), and agreements with fully-fledged investment provisions (e.g. NAFTA (1992)). We only use the latter group to add non-FTA investment treaties. See http://investmentpolicyhub.unctad.org/IIA for the terminological distinction and other examples. (visited 18 May 2015)

67 See UNCTAD database on investor-state disputes, available at: http://investmentpolicyhub.unctad.org/ISDS.
} 
1. Codebook of treaty provisions

International law textbooks emphasize that investment treaties contain a set of core elements. Dolzer and Schreuer refer to common "principles of international investment law." ${ }^{68}$ Montt describes BITs as "a system that contains thousands of investment treaties, all having substantive provisions worded in closely similar terms. ${ }^{, 69}$ For Salacuse, BITs form a global regime of investment protection characterized by common principles, norms, rules and decision-making processes. ${ }^{70}$ In short, there is considerable uniformity in the terms of recurring investment protection clauses.

The uniformity across treaties facilitates the creation of a codebook of frequently encountered clauses. For this paper, we devised an original codebook comprising 55 core investment treaty features relating to three dimensions of IIAs: (1) investment protection, (2) exceptions and (3) investorstate arbitration. To identify representative clauses and their variation, we consulted investment law textbooks, reports by international organization, ${ }^{71}$ BIT model agreements and commentaries ${ }^{72}$ as well as concluded IIA texts. The list regroups the 15 most common investment protection obligations found in IIAs, a range of 23 treaty exemptions, carve-outs and exceptions that limit the scope of these obligations typically vis-à-vis non-investment values, and 17 investor-state arbitration features that curb arbitral discretion either ex ante or ex post reserving control for the contracting parties and outside interests. The specific coding features and coding process is detailed in Annex 1.

\section{Representation of treaty design}

The coding results are used in three different ways to represent treaty design. First, in its raw form, the coding allows us to depict the occurrence of specific treaty features and their changing prevalence over time. We can thus trace, for instance, when general public policy exceptions modeled on trade law's Article XX of the General Agreement on Tariffs and Trade (GATT)

${ }^{68}$ DOLZER AND SCHREUER, supra note 21.

${ }^{69}$ MONTT, supra note 8 at 19.

${ }^{70}$ Jeswald W Salacuse, The Law of Investment Treaties (2010); J. W. Salacuse, The Emerging Global Regime for Investment, 51 HARV INTL LJ 427-553 (2010).

${ }^{71}$ UNCTAD, IDENTIFYING CORE ELEMENTS IN INVESTMENT AGREEMENTS IN THE APEC REGION (2008); UNCTAD, INTERNATIONAL INVESTMENT RULE MAKING: STOCKTAKING Challenges AND THE WAY ForWARD (2009); UNCTAD, Bilateral INVESTMENT TREATIES 1995-2006: TRENDS IN INVESTMENT RULEMAKING (2007); UNCTAD, INTERNATIONAL INVESTMENT ARRANGEMENTS: TRENDS AND EMERGING ISSUES (2006).

72 Chester Brown \& Devashish Krishan, Commentaries on Selected Model INVESTMENT TREATIES (2013). 
were introduced into the IIA universe and how they proliferated over time. Second, we can aggregate individual treaty features into their larger categories, i.e. protection, exception and arbitration, to calculate how many treaty features per category occur in a given treaty and compare that figure across agreements. Third, we can calculate the cumulative score either of the total features per treaty or its substantive (protection and exception) and procedural (arbitration) components to get a sense of a treaty's scope. These three different representations of our coding results thus allow us to produce fine-grained comparisons between agreements.

\section{Research design}

We use our representation of treaty design to investigate the effect of investment arbitration on rule making using both quantitative and qualitative tools. Section 3 begins with a descriptive quantitative analysis of treaty design to set the stage for our causal assessment of clauses, claims and case law in Sections 4-6. In Section 4, we present quantitative evidence, including a regression analysis, to trace the effect of investment clauses on other treaty design elements. Statistical tools, however, are less effective when applied to the impact of claims or case law. As will be further elaborated below, the impact of investment claims tends to be obscured by bi-directional causation as well as intervening or supervening variables difficult to control for in statistical analysis. Investment awards, in turn, are not amenable to regression or event studies as they tend to impact investment treaty making only in the aggregate. Controversial cases spark arbitral disagreement that lead to the creation of different jurisprudential camps, to which states then react through treaty making. Accordingly, Sections 5 and 6 rely more heavily on contextual, qualitative assessments and case studies to reveal the impact of claims and case law on treaty design.

\section{The Evolution of Investment Treaty Design}

In this section we begin by empirically tracing how investment treaty law has changed over time. This analysis creates the basis for our subsequent efforts to attribute treaty design changes to investment clauses, claims and cases.

\section{A. Evolving investment treaty design}

Investment treaties have changed quite drastically since their first inception. Figure 1 traces that change using two different proxies: (1) IIA 
length (in character count) and (2) annual average treaty scores based on 55 coded clauses indexed by 2013 values. The figure shows first that the cumulative count of treaty features is highly correlated (0.95) with treaty length. As can be seen in Figure 1, both proxies of treaty design evolve almost identically. This suggests that our coding of treaty design features captures the changing scope of treaties well without omitting material changes. Second, the figure shows that agreements have gradually increased in length and scope at least since the 1980 s with pace picking up significantly in the last decade.

Figure 1: Annual average scores of treaty length and coded features between 1959 and 2013 (Index Basis: 2013 values)

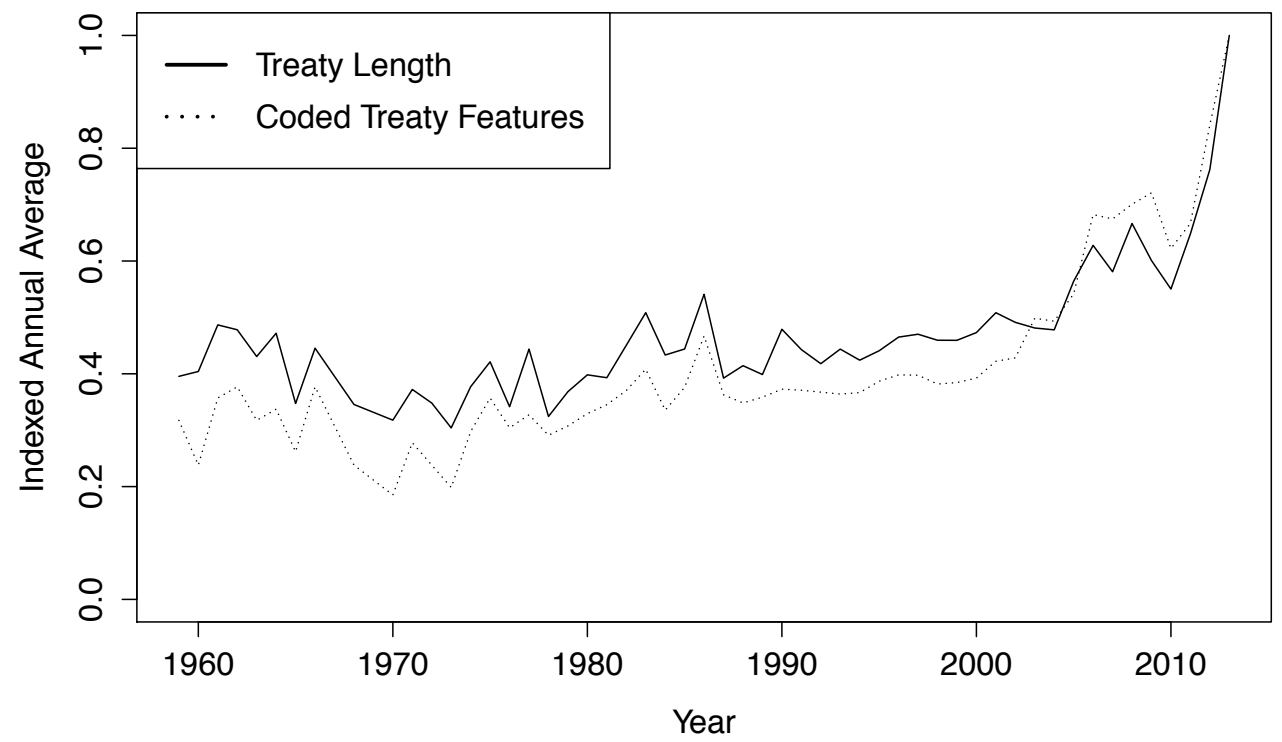

Note: The figure displays annual average scores of 1686 IIAs concluded between 1959 and 2013. The length of a treaty (or investment chapter) is measured by the number of characters it contains. The number of coded treaty features is the cumulative count of 55 coded features per treaty. The annual average is calculated and yearly results are indexed between 0 and 1 as shares of 2013 values.

To better understand what lies behind these changes we need to distinguish between two separate processes: the first appearance of a novel treaty feature and its diffusion in the IIA universe.

\section{B. Mind the gap: The crucial difference between treaty innovation and diffusion}

Treaty design innovation and treaty design diffusion are two separate processes. They need not to co-occur in time nor are they necessarily 
determined by the same causal factors. That is why it is crucial to investigate them separately.

Beginning with the inclusion of new features, Figure 2 identifies when the 55 treaty features we code for first appeared in the investment treaty universe and displays them as cumulative count per year and treaty dimension. It shows that the evolution of IIA treaty design proceeded in several phases of innovation. The first period corresponds to the origins and early days of the IIA universe. The second coincides with the United States' entry into the BIT universe in the early $1980 \mathrm{~s} .{ }^{73}$ Both of these periods are dominated by additions of protective clauses primarily.

Figure 2: Appearance of 55 coded clauses in IIA universe

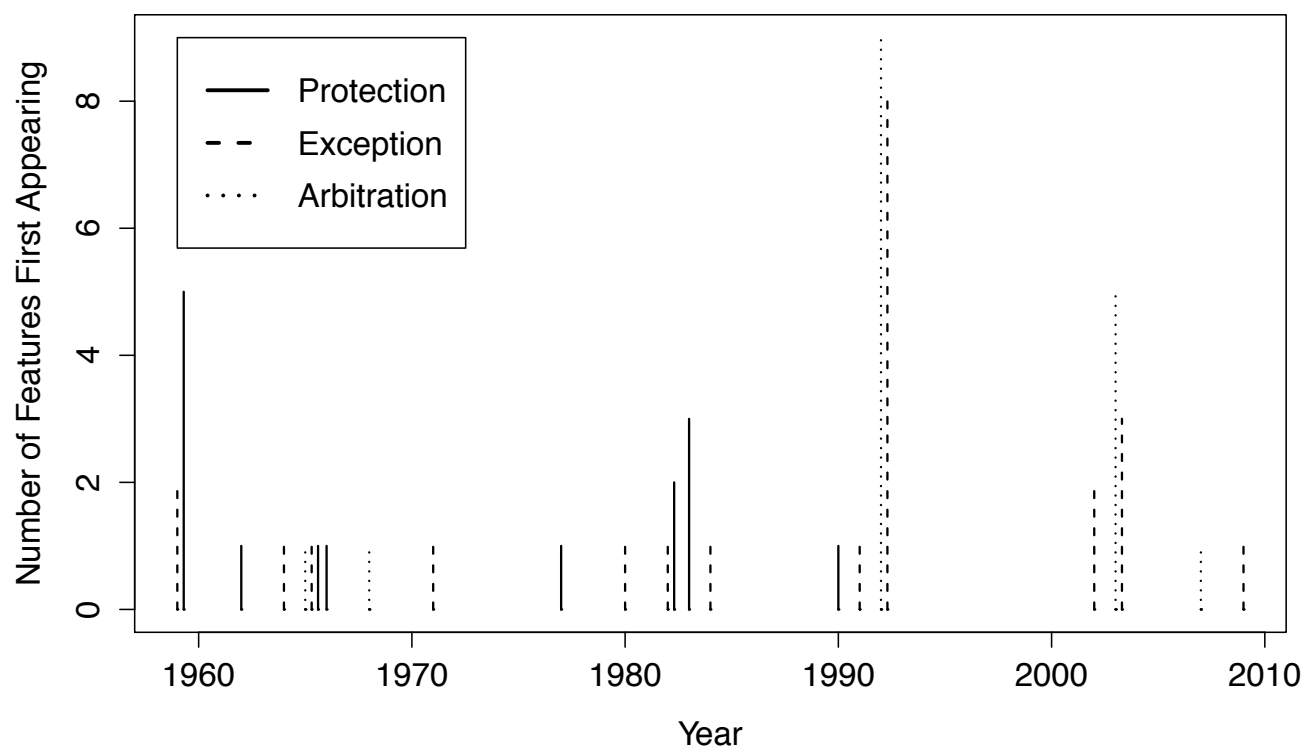

Note: The figure displays treaty features based on the year of their first inclusion. Features are aggregated by category. In 1992, for instance, 9 new exception features and 8 new arbitration features appeared in the IIA universe.

The two latest periods of concentrated innovation - one in the early 1990s and one in the early 2000s - consist primarily of the introduction of new exceptions and investment arbitration control mechanisms. Table 1 lists the individual elements introduced in periods three and four. With respect to the features appearing in the early 1990s, on the exceptions side, we see efforts

\footnotetext{
${ }^{73}$ For a detailed analysis of the impact of the U.S. entry see Wolfgang Alschner, Americanization of the BIT Universe: The Influence of Friendship, Commerce and Navigation (FCN) Treaties on Modern Investment Treaty Law, 5 GoETTINGEN J. INT. LAW 455-486 (2013).
} 
being made to harmonize normative conflicts between investment protection and non-investment values from environmental protection to macro-economic policy. On the arbitration side, we see that states include procedural ex ante and ex post controls in their treaties. From the notice of intent that marks the beginning of the arbitration to the limitation of remedies to a closed list at its end, we see that states define the arbitration process ex ante. In addition, contracting states begin to reserve control mechanisms ex post through authoritative interpretations, the renvoi of certain question of law and fact to the state parties, and the possibility to intervene in the arbitration process as non-disputing state party.

Table 1: Exception and arbitration features appearing in the latest two periods of innovation depicted in Figure 2 above.

\begin{tabular}{|lr|}
\hline \multicolumn{1}{|c|}{ Third Period of Innovation: Early 1990s } \\
Exceptions & $\begin{array}{r}\text { Arbitration } \\
\text { Compulsory License Carve-out }\end{array}$ \\
Creditor Protection & $\begin{array}{r}\text { Loss or Damage } \\
\text { Culture }\end{array}$ \\
Environmental Measures Clause & Limitation Periods for Claims \\
GATT XX & Waiver of Other Proceedings \\
Exchange Rate Measures Carve-out & Consolidation \\
Prudential Measures Carve-out & Closed List of Remedies \\
Subsidies Carve-out & Authoritative Interpretation \\
& Renvoi to State Parties \\
$\quad$ Fourth Period of Innovation: Early 2000s \\
& State-party Participation \\
& Arbitration \\
Exceptions & Transparency of Proceedings \\
Indirect FET Breach Carve-out & Amicus Curiae \\
MFN Non-application to ISA & Preliminary Objections \\
Bona Fide Taking Carve-out & Comment Procedure on Draft Award \\
Indirect Expropriation Definition & Appellate Mechanism Proposal \\
Investment Characteristics & \\
FET linked to CIL & \\
\hline
\end{tabular}

In comparison to these extensive and quite radical changes, the fourth period elements constitute targeted refinements. On the exception side, we see efforts to clarify key treaty provisions from the definition of investment, to the scope and content of fair and equitable treatment (FET), most-favored-nation (MFN) clauses or expropriation. On the arbitration side, we see an integration of outside interests into the arbitration process through transparent proceedings 
and amicus curiae submissions in addition to more state control mechanisms such as comment procedures for draft awards or appellate review proposals.

Shifting from the first inclusion of these treaty design features to their proliferation we see important differences, but also common trends. Figure 3 traces the evolution of the coded treaty design dimensions protection, exception and arbitration over time. All three dimensions display a small, but gradual growth over time. Protection scores increased particularly in the 1970s and ' $80 \mathrm{~s}$, as well as over the past five years. In contrast, exception and arbitration scores only really began to surge during the past decade. Hence, both in their first inception and their proliferation, protective obligations tend to pre-date exceptions and arbitration control mechanisms.

Figure 3: Evolution of the three coded categories in IIAs since 1968 (Index Basis: 2013 values)

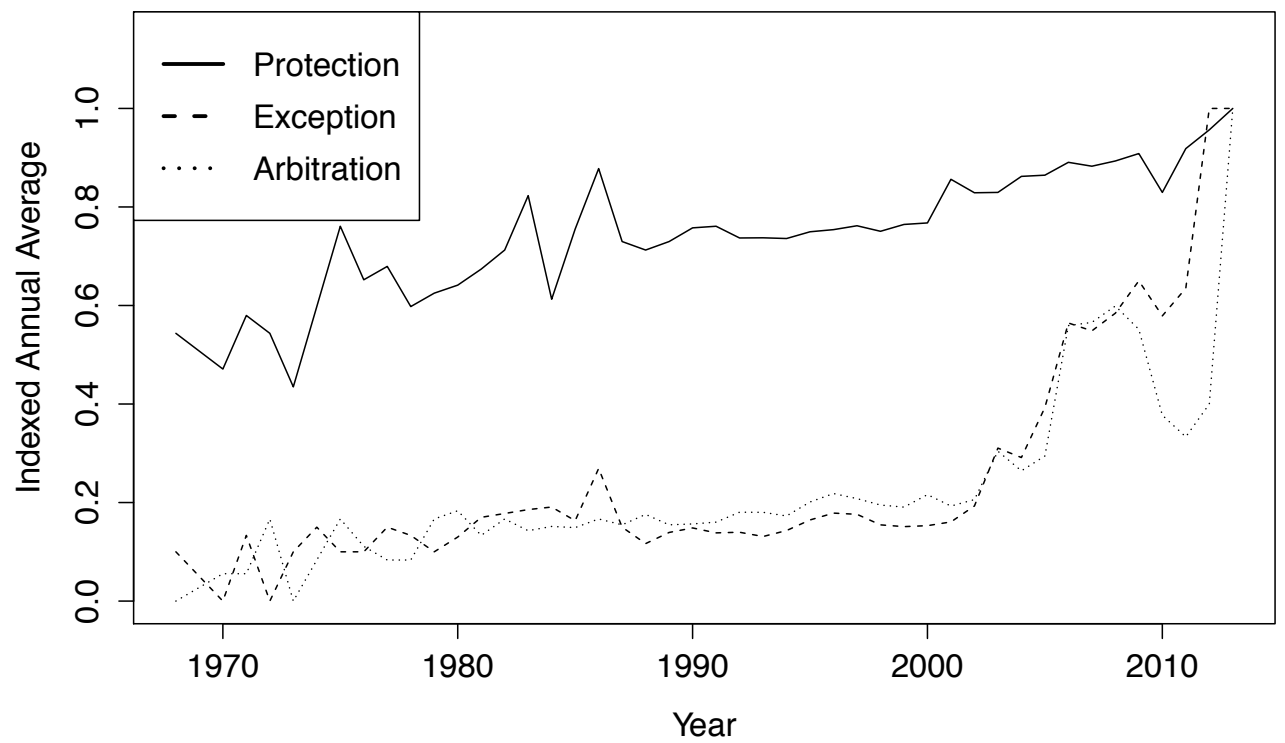

Note: The figure displays protection, exception and arbitration scores of IIAs concluded between 1968 and 2013. For each year, the average of scores of treaties concluded that year is taken for the three categories. The yearly results are then indexed between 0 and 1 as shares of 2013 values.

An important difference, however, lies in the timing of the first appearance of treaty features and their diffusion. The features first introduced in period 3 spread only marginally in the IIA universe in the 1990s and early 2000s. Only after period 4 innovations had already occurred, did the features of these two periods of innovation diffuse more broadly in the IIA universe. By 2013, on average, every second treaty signed contained period 3 features and every third 
treaty had period 4 elements. Taking account of this gap between treaty innovation and diffusion is thus likely to be key in isolating and understanding the impact of investment arbitration.

\section{Developments in investment arbitration}

Shifting from the effects we want to explain, i.e. treaty design changes, to their potential causes, Figure 4 traces the evolution of the three investment arbitration impact channels identified above: (1) the inclusion of investment clauses, (2) the yearly count of investment claims and (3) the yearly count of investment awards rendered.

Figure 4: Evolution of the three investment arbitration impact channels (Index Basis: 2013 values)

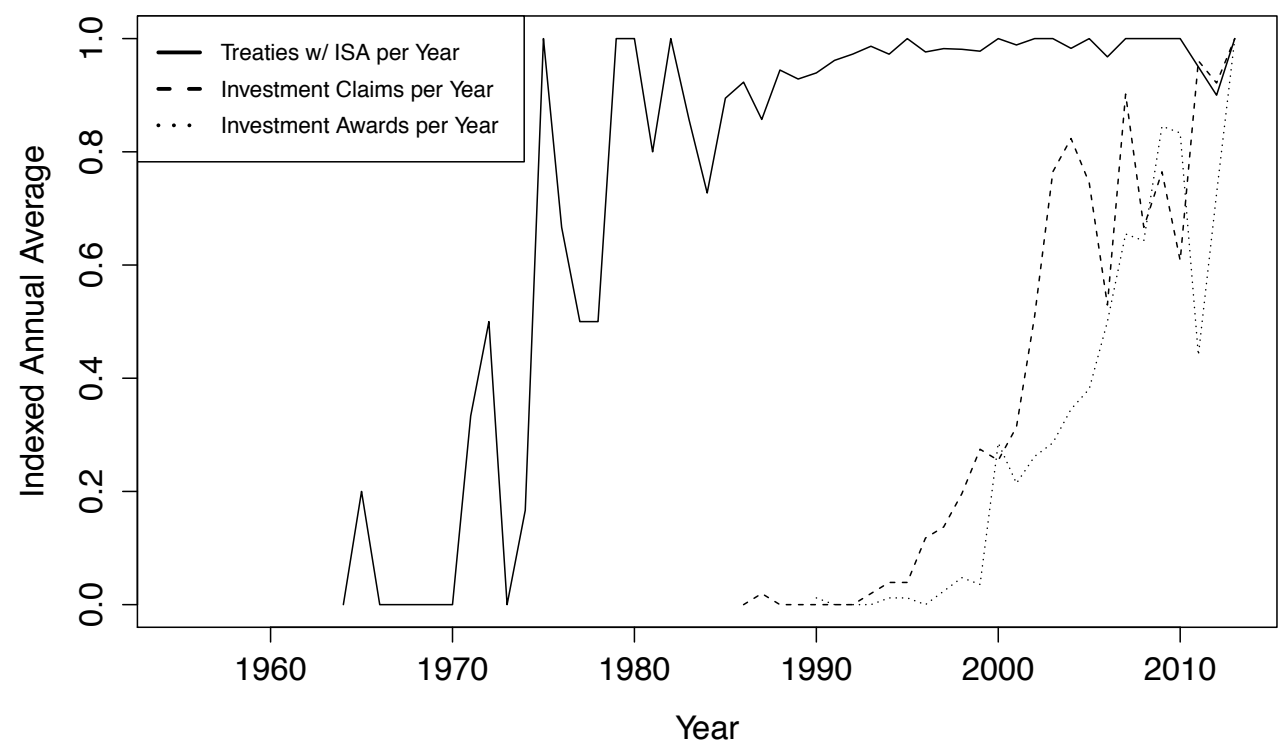

Note: The figure displays the development of the three ISA impact channels between 1959 and 2013. The existence of ISA clauses is represented as share of IIAs concluded per year that contain consent to ISA normalized by 2013 values (all treaties concluded that year in our database contain consent to ISA). Investment claims are measured as number of claims filed per year and normalized by 2013 values (51 claims were submitted in 2013). Finally, investment awards data is scraped from italaw.com and includes all awards and decision of treaty-based investment tribunals rendered per year and normalized by 2013 values ( 81 awards and decisions were rendered in 2013).

We see a steady increase in all three variables. First, investor-state arbitration clauses began to appear in the IIA universe shortly after the conclusion of the ICSID Convention and became virtually ubiquitous in the 1990 s with a small dip in recent years as countries, like Australia, stopped 
including ISA provisions in their treaties. ${ }^{74}$ Second, investment claims began to increase sharply in the late 1990s and have continued to increase with more than 50 claims being filed in 2013. Third, with a three to five year delay from the commencement of arbitration claims, we also observe a steady growth of investment case law from 2000 onward.

In the remainder of this article, we will bring the different pieces of data together linking developments in investment arbitration to changes in treaty design. A cursory comparison of the figures presented in this section already suggests that the interplay between investment arbitration and investment treaty design is a complex one: few if any significant treaty-design changes seem to coincide in time with major changes in investment arbitration; numerous treaty design innovations like those in the early 1990s either postdate (compared to investment clauses) or pre-date (compared to the surge of investment claims) developments in investment arbitration and stark changes in treaty design seem to have occurred well after the first proliferation of investment disputes and awards. Hence, we will need to engage in a nuanced investigation that distinguishes between treaty design changes that can be convincingly attributed to investment arbitration clauses, claims or cases and those that may be due to others factors.

\section{The IMPACT OF ARbitration Clauses on Rule MAKING}

The first of the impact channels we identified were investment clauses. How does the inclusion or omission of an ISA clause affect treaty design? Do states, for instance, lower the degree of investment protection offered by their treaties or include specific procedural safeguards when they choose to let an IIA be enforced through investor-state arbitration? As this section will show, investment clauses do not have a material impact on the other treaty design elements we coded for. This non-finding, however, has important normative implications.

\section{A. No material impact on treaty design}

In Section 1 we hypothesized that treaties with ISA would display procedural ex ante and ex post controls over the arbitration process and possess fewer investment protection features than treaties without it. Surprisingly, however, we find that ISA's inclusion has not been accompanied by other systematic treaty design changes of a meaningful magnitude.

\footnotetext{
${ }^{74}$ See Section 4 below for a discussion of the Australian policy change.
} 
1. ISA clauses and procedural safeguards

On the procedural side, contrary to the expectation derived from the WTO experience that more law (e.g. stronger enforcement) requires more politics (e.g. extra-judicial flexibility), states did not accompany ISA clauses with control mechanisms when they first decided to let investors enforce their IIAs. $^{75}$ Prior to 1990 , almost none of BITs with ISA included additional procedural safeguards. At most, agreements contained 1 out of the 16 ex ante and ex post arbitration controls we coded for. These treaties, for instance, establish committees of state representatives charged with monitoring the agreement's application. $^{76}$

Differently put, in most early BITs with ISA signed prior to 1990 no interstate interaction is foreseen short of formal state-to-state dispute settlement. Accordingly, the home state is excluded from taking any part in the ISA process. The ISA procedure itself is sketched out in little detail leaving it not to the contracting parties but to the disputing parties, or if they cannot agree, to the arbitrators to mold the proceedings. ${ }^{77}$ Hence, with little procedural guidance ex ante and no means of intervention into the ISA dispute settlement process ex post, the contracting states did not accompany the inclusion of ISA clauses into early BITs with a set of procedural control mechanisms.

2. ISA clauses and substantive treaty design differences

While ISA clauses were not accompanied by more widespread procedural changes in treaty design, did they trigger changes in the substantive content of IIAs, e.g. prompting a reduction of protective clauses or an increase of exception provisions? A comparison of the protection and exception dimension in IIAs with and without ISA suggests that ISA clauses do not lead to material differences of substantive treaty content.

Figure 5 compares the summary statistics of IIAs with and without ISA as boxplots. We see that both types of agreements display similar levels of exception and protection scores. The majority of treaties in either category have only between 0 and 2 exceptions. When it comes to protection features, most treaties without ISA range between 5 and 7 clauses, while IIAs with ISA

75 At the same time, not all of these early BITs contained comprehensive ISA clauses either. For a typology and prevalence of different ISA clauses see Yackee, supra note 18.

${ }_{77}^{76}$ See e.g. Netherlands-Singapore BIT (1972) Article XIII.

77 Article 10(2) of the Germany-Nepal BIT (1986) is a case in point. It merely refers disputes to ICSID arbitration without specifying the arbitration procedure or reserving a right for non-disputing parties to take part or to intervene. 
are placed slightly higher between 6 and 8 protection clauses. Hence, apart from a slight difference in protection features, treaties with and without ISA are strikingly similar.

Figure 5: Comparing IIAs with and without ISA between 1959 and 2013 in terms of their substantive scope (exception and protection)

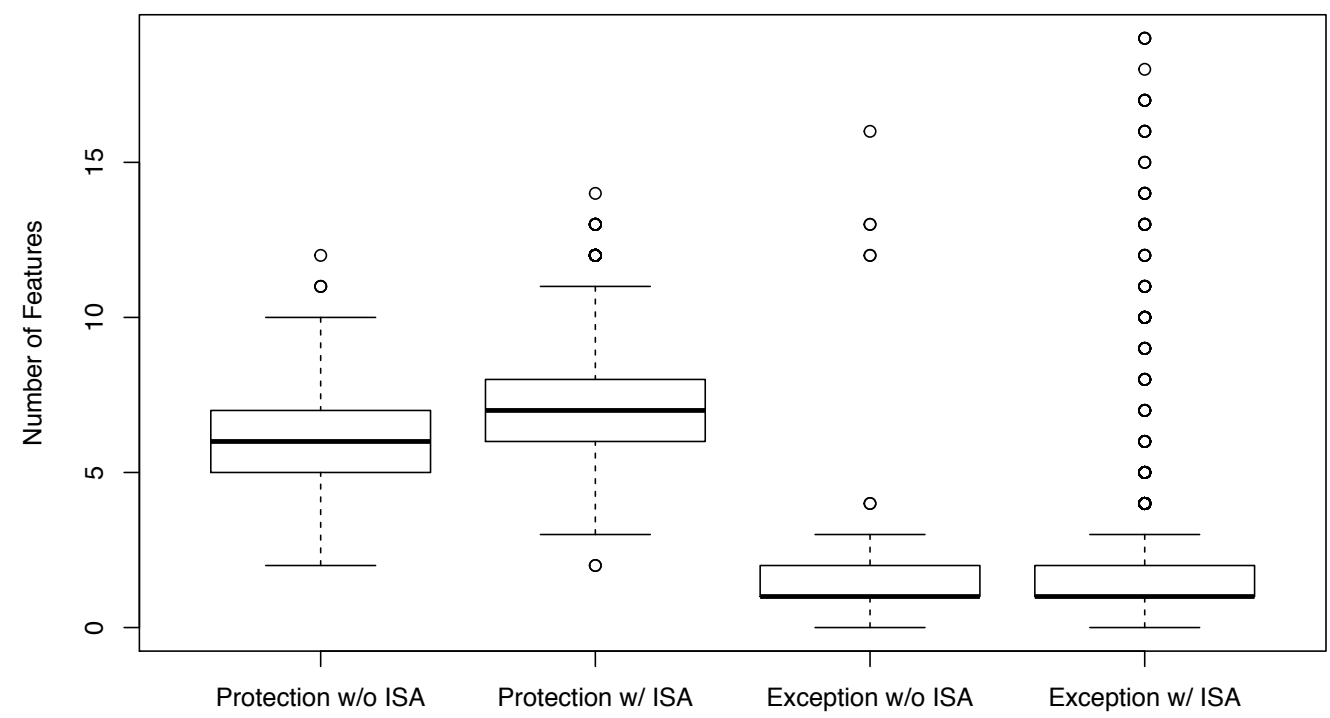

Note: The figure compares IIAs with and without ISA between 1959 and 2013 as boxplots. The central box marks the $50 \%$ of observations around the median (black line). The median is 6 and 7 for protection clauses without and with ISA respectively and 1 for exceptions in both groups. The "whiskers" show upper and lower quartiles representing the range of observations with dots being outliers.

In spite of this general similarity, did ISA clauses perhaps trigger treaty design changes when they were first introduced? To answer that question we focus on the initial twenty years of the IIA universe between 1959 and 1979, which marked the gradual transition from BITs without ISA to BITs with ISA. We run a Poisson Regression with the existence of an ISA clause as independent variable and the coded treaty scores of protection and exception levels as dependent variables respectively. We control for differences stemming from the richer treaty partner, as prior research found that developed countries differ in the treaty templates they employ and that these templates have a strong impact on treaty design outcomes. ${ }^{78}$ The results are reported in summary form in Table $2 .^{79}$

\footnotetext{
${ }^{78}$ Alschner and Skougarevskiy, supra note 6.

${ }^{79}$ I am grateful to Dmitriy Skougarevskiy for his guidance on the regression design.
} 
Table 2: Results of a Poisson regression of BITs between 1959 and 1979 investigating the link between the inclusion of ISA clauses and substantive treaty design (Protection and Exception Scores)

\section{Dependent variables:}

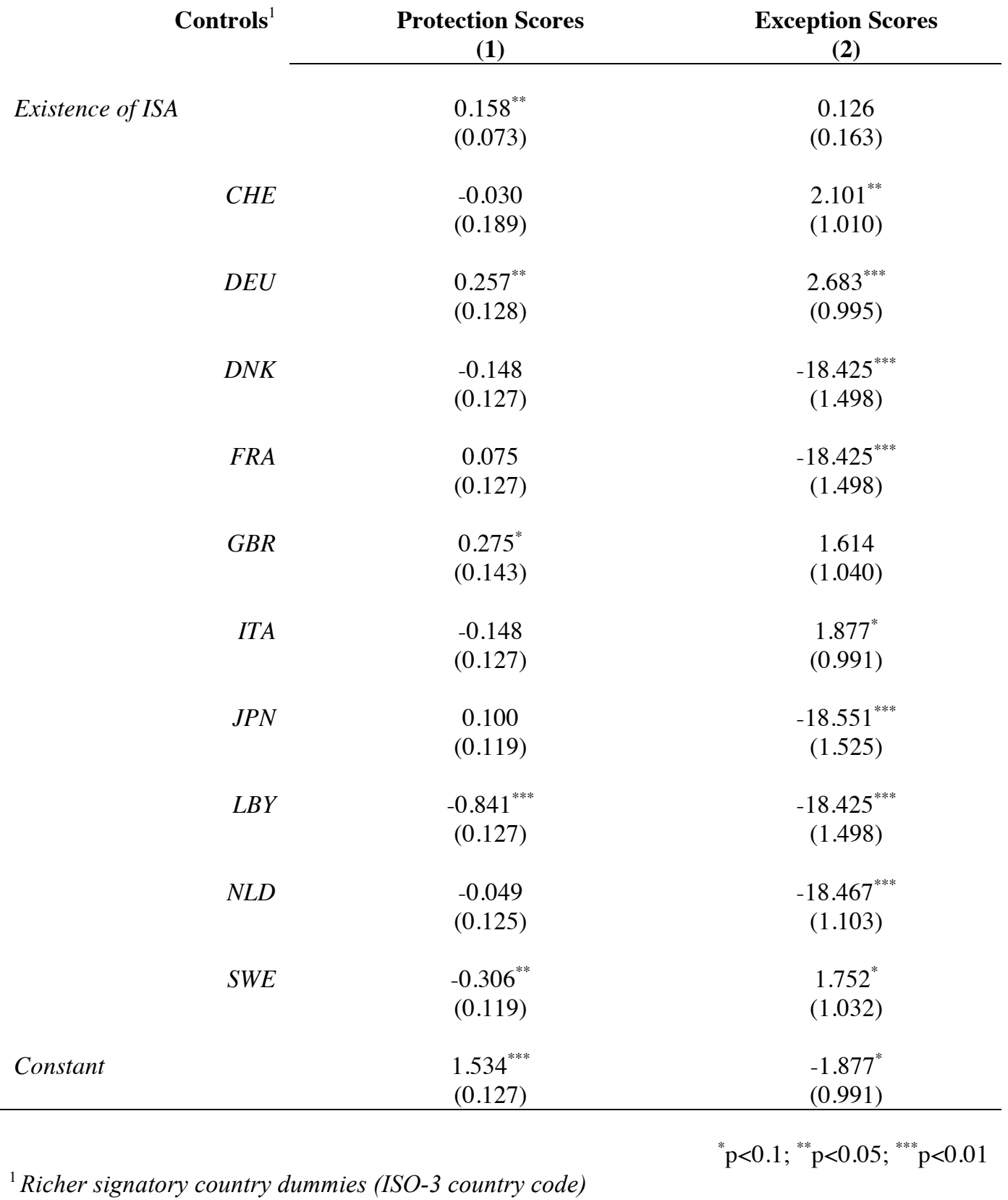


The regression results show a statistically significant positive effect of ISA clauses on protection clauses - albeit with a very small magnitude. About every sixth BIT with ISA clause will have one protective clause more than a BIT without ISA. ISA clauses do not, however, have any statistically significant effect on a BIT's propensity to include exception clauses. Therefore, contrary to our expectation, the inclusion of ISA clauses did not lead to a material redesigning of IIAs. On the one hand, it increased rather than decreased the protective dimension of a treaty - albeit only very slightly. On the other hand, states did not increase exceptions in their BITs to mitigate the impact of ISA on policy space. This absence of a larger effect of ISA clauses on the substantive scope of BITs suggests that states when they first introduced ISA clauses did not consider them to warrant a transformation of treaty design more generally. They merely saw ISA clauses as self-standing procedural addons.

When we look at more modern IIAs with and without ISA this assessment does not change. In April 2011, the Australian government announced that it would refrain from including ISA clauses in future IIAs. ${ }^{80}$ Comparing the substantive protection and exception dimension of the treaties signed immediately prior to this shift in policy (i.e. Australia-Chile FTA (2008) and ASEAN-Australia-New Zealand FTA (2009)) with those treaties signed after it with New Zealand (2011), Malaysia (2012) and Japan (2014) we do not find any systematic variation in treaty design between ISA and non-ISA treaties. 11 out of the 15 protection clauses and 16 out of the 23 exception clauses do not vary across the five agreements. More importantly, of the remaining 11 features that do vary, not one of them clusters in groups of ISA versus no ISA treaties. Hence, Australia considered ISA clauses as something it could include or omit in its treaties without having to adjust the agreements' substantive scope.

Finally, recent investment treaty practice provides an even more striking illustration of the non-impact of ISA clauses on other substantive treaty design elements. The TPP concluded in October 2015 contains an investment chapter with an ISA mechanism. ${ }^{81}$ Australia and New Zealand, however, agreed in a letter exchange to preclude its investors from having recourse to ISA against

\footnotetext{
${ }^{80}$ See Australian Government, Department of Foreign Affairs and Trade, Gillard Government Trade Policy Statement: Trading our way to more jobs and prosperity, April 2011, $14, \quad$ available at: http://blogs.usyd.edu.au/japaneselaw/2011_Gillard\%20Govt\%20Trade\%20Policy\%20Sta tement.pdf.

${ }^{81}$ For an in-depth discussion, see Alschner and Skougarevskiy, supra note 36.
} 
the other party respectively. ${ }^{82}$ That means that identical TPP investment obligations and exceptions are enforceable by investors and their home states in some bilateral relationships and exclusively by the home states in others. The choice of enforcement mechanism is thus independent from the substantive content of an IIA.

\section{B. Implications for normative debates}

The empirical analysis revealed that the introduction of ISA clauses has not been accompanied by material treaty design alterations. We can draw two key lessons from that.

1. Procedural controls and the depoliticization of investment disputes

Considered in light of the historical context, the decision not to add further procedural safeguards when ISA clauses were first introduced seems to have been a conscious design choice rather than an oversight by the treaty drafters. Depoliticizing investment disputes and pacifying international relations was a major impetus for the development of investor-state arbitration in the 1960s: it was thought that by enabling private investors to sue host states, ISA would prevent investment disputes from becoming inter-state disputes. ${ }^{83}$ Accordingly, BITs with ISA involved a basic bargain for both home and host states: home states would refrain from vindicating the rights of their nationals abroad as long as host states would agree to have disputes settled with these foreign investors before international arbitration. ${ }^{84}$ The exclusion of inter-state or home state control mechanisms over investor-state arbitration was thus an intentional design feature to depoliticize investment disputes. ${ }^{85}$

Whether the same rationale of depoliticization still justifies the exclusion

82 Exchange of letters Australia - New Zealand: Investor State Dispute Settlement, Trade Remedies and Transport Services, available at: http://dfat.gov.au/trade/agreements/tpp/official-documents/Pages/officialdocuments.aspx.

${ }^{83}$ BROCHES, supra note 14 at 163; Shihata, supra note 14; See generally PARRA, supra note 14. Also the ICSID Convention provided in Article 27 that home states are precluded from exercising diplomatic protection vis-à-vis investors while an investorstate arbitration is ongoing.

${ }^{84}$ Pauwelyn, supra note 26 at $402-404$.

${ }^{85}$ As we saw in Figure 3 above, starting in the 1990s and gaining traction in the 2000s, we see a partial reversal of that policy and a "return of the state" as more procedural ex ante and ex post controls are inserted into IIAs to accompany ISA clauses. See Alvarez, supra note 3; Alschner, supra note 37. We will further discuss this policy change in the next section as it coincided with the spread of investment claims rather than investment clauses. 
of procedural state controls today, however, is doubtful. The risk of investment disputes spiraling into inter-state conflict is lower today than it was at the time of ICSID. Ideological divides have given way to embedded liberalism and international organizations ensure constant inter-state dialogue and provide mechanisms for the peaceful settlement of disputes. ${ }^{86}$ Indeed, empirical research shows that high-level political pressure over investment issues has become extremely rare. ${ }^{87}$ At the same time, investor-state dispute settlement itself has turned from a vehicle of depoliticization into a driver of politicization through the controversies surrounding it. ${ }^{88}$ It today divides states into ISA supporters (e.g. United States), opponents (e.g. Venezuela) and reformers (e.g. European Union). As a result, justifications prominent in the 1960s should not stand in the way of a more important role of procedural safeguards today. Recalling the mutually beneficial interaction of law and politics at the WTO discussed above, infusing more inter-state politics into investment law may be the best recipe to attenuate the increasingly controversial perception of ISA. Recent treaty practice suggests that such development is well underway. ${ }^{89}$

2. Substantive investor rights? ISA clauses as mere procedural add-ons

Turning to the substantive treaty dimension, the empirical analysis revealed that ISA clauses are procedural add-ons whose inclusion or omission does not materially alter the substantive content of an IIA. Apart from a slight propensity to be more protective, IIAs do not systematically vary depending on whether they contain ISA or not. This finding should thus add a qualification to assertions that ISA clauses are to be viewed as transformative of IIAs. While the inclusion of ISA clauses in IIAs has undoubtedly impacted the practice of investment law, their inclusion or omission had much less effect on treaty design. Negotiators do not design their agreements differently depending on whether they draft an IIA with or without ISA.

This insight has important normative implications. First, it helps us to reevaluate claims that ISA changed the "nature" of BITs. The nature of IIAs, and in particular, the nature of its substantive obligations, is a hotly debated issue in international investment law scholarship. One camp posits that the

${ }^{86}$ Kenneth J. Vandevelde, Of Politics and Markets: The Shifting Ideology of the BITs, 11 InTL TAX Bus LAW 159 (1993); see also John Gerard Ruggie, International Regimes, Transactions, and Change: Embedded Liberalism in the Postwar Economic Order, 36 INT. ORGAN. 379-415 (1982).

${ }^{87}$ Geoffrey Gertz Srividya Jandhyala Lauge N. Skovgaard Poulsen, Legalization and Diplomacy: American Power and the Investment Regime, Working Paper, (on file with the author).

${ }^{88}$ On ISA controversies, see the discussion above at notes 21 and 22.

${ }^{89}$ Roberts, supra note 57; UNCTAD, supra note 54; Alschner, supra note 37. 
substantive obligations contained in IIAs are only owed towards the other state party and that investor rights are procedural, but not substantive in nature. ${ }^{90}$ Another camp asserts that the protective obligations in IIAs are owed to the other contracting states and their investors directly. ${ }^{91}$ Some go even further arguing that IIAs are like "contracts for the benefit of third parties" and are to be enforced primarily by investors and only secondarily by states. ${ }^{92}$ Which camp is right has significant implications for a myriad of practical legal questions on how inter-state affairs affect investor-state relations and vice versa. If substantive investment treaty rights are owed to states alone, a host state can, for instance, rightfully suspend them as countermeasures without paying compensation in response to an internationally wrongful act by the home state; in contrast, if they are owed to the investor, such an internationallaw-compliant retaliation does not absolve the host from the obligation to pay compensation to the home state's investors aggrieved thereby. ${ }^{93}$ Similarly, if substantive treaty rights are vested in states, home governments can settle investment disputes over the heads of their investors; yet if these rights actually belonged to the individuals, investors could veto any such settlements or re-litigate disputes already settled between the contracting parties. ${ }^{94}$ Finally, substantive investor rights would also mean that investors could waive treaty protection in investment contracts; if, however, the rights were those of the home state then it would not be in the investor's power to forego them. ${ }^{95}$ Our analysis sheds new light on these and related legal debates by revealing that ISA's impact is purely procedural: through an ISA clause a second enforcement route is added next to the state-to-state dispute settlement procedure; no material and systematic impact on investment treaty substance

${ }^{90}$ Archer Daniels Midland Company and Tate \& Lyle Ingredients Americas, Inc. v. The United Mexican States, ICSID Case No. ARB (AF)/04/5, Award (Nov. 21, 2007) \173. ZACHARY DOUGLAS, THE INTERNATIONAL LAW OF INVESTMENT CLAIMS 35 (2009). (The substantive obligations are merely "applicable adjudicative standards for the claimant's cause of action rather than binding obligations owed directly to the investor".)

91 Corn Products International, Inc. v. United Mexican States, ICSID Case No. ARB (AF)/04/1, Decision on Responsibility (Jan. 15, 2008) 9 174. See also Tillmann Rudolf Braun, Globalization-driven Innovation: The Investor as a Partial Subject in Public International Law - An Inquiry into the Nature and Limits of Investor Rights -, 04/2013 JEAN MONNET WORK. PAP., 37.

92 Republic of Ecuador v. United States of America (PCA Case No. 2012-5), Expert Opinion with Respect to Jurisdiction, Prof. W. Michael Reisman (Apr. 24, 2012) ๆ 3.

93 M. Paparinskis, Equivalent Primary Rules and Differential Secondary Rules: Countermeasures in WTO and Investment Protection Law, (2010).

94 Anthea Roberts, State-to-State Investment Treaty Arbitration: A Hybrid Theory of Interdependent Rights and Shared Interpretive Authority, 55 HARV. INT. LAW J. (2014).

95 Z. Douglas, The Hybrid Foundations of Investment Treaty Arbitration, 74 BR. YEARB. INT. LAW 151-289 (2004); ZACHARY DOUGLAS, THE INTERNATIONAL LAW OF INVESTMENT CLAIMS 1 (2009). 
was detected. This empirical insight thus suggests that the more convincing view is that ISA clauses create procedural, but not substantive investor rights. ${ }^{96}$

Second, the independence of enforcement and substance may also affect how an investment treaty is to be interpreted. The existence of investor-state arbitration has given rise to an individualized conception of key protective provisions. Tribunals assess compliance with fair and equitable treatment based on whether the investor's individual legitimate expectations were violated rather than those of its home state. ${ }^{97}$ Similarly, when determining whether a third treaty clause should be incorporated by reference into the base treaty through MFN, more favorable treatment is measured vis-à-vis the particular claiming investor and not in relation to an abstract class of home state investors or vis-à-vis the home state itself. ${ }^{98}$ Finally, with respect to national treatment, tribunals and scholars have argued for differing interpretations between trade and investment regimes on the basis that the former is about competitive opportunities between states, while the latter is about protecting individual rights. ${ }^{99}$ The interpretation of IIA provisions, which are typically phrased as inter-state promises, in such an individualized light draws its justification from ISA's enforcement procedure. The conceptual separation of procedure and substance in IIAs may thus prompt us to reconsider the merits of a more state- rather than investor-centric interpretation of IIAs' protection clauses.

Finally, the insight that ISA clauses are procedural add-ons that leave substantive IIA obligations unaffected gives flexibility to investment treaty drafters to tweak the system's enforcement architecture. Whether negotiators want to reform ISA, replace it with an investment court system as suggested by the EU, or omit it entirely opting for a WTO-like state-to-state dispute settlement system instead, they can do so independently of any concurrent reform of the treaties' substance. Similarly, the disconnect between substance

${ }^{96}$ While this does not disprove the point that the inclusion of ISA may have implicitly affected the nature of IIA's substantive obligations, it places a higher burden of persuasion on proponents of the substantive investor rights view to show why the original inter-state nature of IIA obligations has been altered although no explicit change in substantive treaty content is empirically apparent.

${ }^{97}$ M. Potesta, Legitimate Expectations in Investment Treaty Law: Understanding the Roots and the Limits of a Controversial Concept, 28 ICSID REV. 88-122 (2013).

98 Tony Cole, The Boundaries of Most Favoured Nation Treatment in International Investment Law, 33 Mich. J. INT. LAW 537 (2012).

${ }^{99}$ Nicholas DiMascio \& Joost Pauwelyn, Nondiscrimination in Trade and Investment Treaties: Worlds Apart or Two Sides of the Same Coin?, 102 AM. J. INT. LAW 48-89 (2008). 
and procedure allows for the multilateralization of enforcement without multilateralizing substance replacing treaty-specific ad hoc tribunals with a standing multilateral body while leaving bilateral treaties in place. In short, the insight that ISA is a mere procedural add-on helps negotiators to reform investment law.

\section{The IMPACT OF ARbitration Claims ON RULE MAKING}

The puzzle remains, why states did not react to the inclusion of ISA clauses by changing the design of IIAs given ISA's potentially more severe impact on sovereignty as compared to inter-state arbitration. Did they specifically intend to leave treaty design otherwise unchanged? Or did they perhaps misunderstand the true potential of ISA enforcement and were surprised when, 30 years after ISA's first inclusion, investment claims suddenly began to proliferate? When states then learned about the implications of ISA, did they respond by lowering investment protection and by adding defensive elements to their treaties to mitigate the adverse impact of ISA on their policy space? To find answers to these questions we turn to the second impact channel - the effect of investment claims on treaty design.

\section{A. Learning from claims?}

To measure the impact of investment claims, we first have to understand the causal mechanisms by which they affect treaty design. Scholars investigating the effect of investment claims typically start from the premise that states may have underestimated or misunderstood the full potential of ISA. ${ }^{100}$ From that premise onwards, however, opinions diverge how best to explain how states learn from investment claims and alter their treaty design. One theory posits that states may be Bayesian learners updating their treaty design preferences when new information becomes available. ${ }^{101}$ Under a second theory, states are assumed not to act perfect-rationally, but boundedrationally, only changing their treaties when they themselves become subject

\footnotetext{
${ }^{100}$ See supra Section 1.

101 A Bayesian learner theory arguably underlies most legal scholarship on the subject supposing that states learn generally from investment disputes around the world. See, for instance, UNCTAD, supra note 4 at 71 ("It is evident that the significant increase in the number of ISDS claims over the last decade has had an impact on the process of investment rulemaking. ISDS practice has led numerous countries to realize that the specific wording of IIA provisions does matter, and that it can make a significant difference to the outcome of an investment dispute. Thus, it is no coincidence that several countries in the Asia-Pacific region recently revised their model IIAs and updated their wording, content and structure to incorporate the lessons learned from investment-related litigation experience.").
} 
to an investment claim and immediately feel its adverse impact. ${ }^{102}$ As we will show in the following, regardless of which theory is investigated, scholars need to account for bi-directional causal effects and unobserved intervening or supervening variables; moreover, they need to clearly distinguish between what treaty design change is measured - innovation or diffusion - to unveil the causal mechanisms connecting claims and treaty design.

\section{Bayesian learners}

If states were Bayesian learners, then the first information that they could have used to update their knowledge about ISA's true implications would have been the first treaty-based investment claim $A A P L$, which was admitted in a 1990 decision. ${ }^{103}$ As discussed above, $A A P L$ was the first tribunal to recognize the initially controversial position that an ISA clause in an IIA provides the investor with a direct means of recourse to enforce treaty violations before international arbitration. We would then expect to observe treaty design changes being introduced in the early 1990s in the wake of that decision.

\section{Bounded rational learners}

The alternative theory posits that states only reacted to investment claims when they felt the detrimental consequences of ISA themselves and not by learning about claims against others. Investigating the impact of investment claims on treaty signing patterns Poulsen and Aisbett, for instance, find that developing countries tended to sign less investment treaties only when they were hit by investment claims themselves rather than in response to investment claims generally. ${ }^{104}$

The underlying idea derived from behavioral sciences is that decision makers tend to "rely excessively on information that is vivid and easily available". 105 Information about claims against other states is both emotionally remote due to optimism bias ("this will never happen to us") as well as costly to obtain. In contrast, being hit by a claim is an immediate and vivid experience. This then results in a bias in information processing as states fail to react to readily available information until they themselves become a target for

102 Lauge Poulsen, SaCrificing Sovereignty by Chance: Investment Treaties, DeVeloping Countries, AND Bounded RATIONAlity (2011); Poulsen, supra note 46; Lauge Poulsen \& Emma Aisbett, When the Claim Hits: Bilateral Investment Treaties and Bounded Rational Learning, 65 WORLD POLIT. 273-313 (2013).

${ }^{103}$ Asian Agricultural Products Ltd. v. Republic of Sri Lanka, ICSID Case No. ARB/87/3, Final Award (June 27, 1990).

${ }^{104}$ Poulsen and Aisbett, supra note 103.

${ }^{105}$ Poulsen, supra note 46 at 5. 
investment claims.

Which theory better corresponds to reality is a matter of empirical analysis. Yet, in order to empirically verify one or the other theory, researchers have to isolate the causal impact of investment claims from other factors that may influence investment treaty design.

3. Limitations of existing econometric evidence and the need for context

Econometric studies are used in deductive empirics to find causal relationships. In the context of investment claim's impact on treaty design, they have yielded mixed results. Manger and Peinhardt found that both learning from claims against others (Bayesian updating) as well as claims against the home state (bounded rationality) lead to treaty design change. ${ }^{106}$ They conclude that states add "precision" to their treaties, modeled alternatively as an aggregate count of coded clauses or treaty length, in response to investment claims.

Opting for a different research design Dmitriy Skougarevskiy and I concluded that being hit by a claim does not cause treaty design innovation. ${ }^{107}$ We focus on textual innovation rather than changes in coded clauses or treaty length and account for a potential endogeneity of claims and treaty design by including an instrumental variable. Even if we allow for a lagged impact, we do not find any statistically significant effect of investment claims against the richer state. We did not test the Bayesian updating theory.

In order to properly understand the impact of investment claims, we need to move beyond existing studies. First of all, as we saw in Section 3, there is a gap between treaty innovation in the early 1990s and 2000s and their diffusion starting in the second half of the 2000s. Earlier work focuses either on innovation or diffusion, yet only if we investigate both dimensions and understand the gap between them, we can accurately describe the impact of investment claims. Second, econometric studies investigating the impact of investment claims struggle with omitted variable bias making alternative, more contextual research strategies more viable. On the one hand, we need contextual knowledge to understand whether bi-directional causation is at work: investment claims may lead to treaty design variations, but also, vice versa, treaty design variations may lead to investment claims. On the other

\footnotetext{
${ }^{106}$ Manger and Peinhardt, supra note 4.

${ }^{107}$ Wolfgang Alschner \& Dmitriy Skougarevskiy, Consistency and Legal Innovation in the BIT Universe, STANF. PUBLIC LAW WORK. PAP. (2015), http://papers.ssrn.com/abstract=2595288 (last visited Apr 28, 2015).
} 
hand, contextual knowledge is also required to identify alternative causal factors diluting, enhancing or impeding any impact of investment claims on treaty design. In particular, we need to investigate whether, how and why responses to investment claims may vary across countries. Although, sophisticated econometric studies employing instrumental variables, better control variables, and/or fixed effects may be able to overcome these difficulties, a pre-condition to any such exercise is a thorough contextual understanding of the interaction between different variables. In the remainder of this section we therefore provide such a contextual account using case studies and distinguish between innovation and diffusion as variables to be explained.

\section{B. Treaty design innovation and investment claims}

We begin by analyzing the causal impact of claims on treaty design innovation looking at the two periods of innovation that coincide with the surge of investment claims - period 3 innovations from the early 1990s and period 4 innovations from the early 2000 s.

1. Innovation in the early 1990s: Anticipating rather than reacting to investment claims

What caused the inclusion of new treaty design features in the early 1990s? Almost all the elements (apart from GATT XX type exceptions) introduced in this period we coded for can be linked to one agreement: the North American Free Trade Agreement (NAFTA). In NAFTA, Canada, Mexico and the United States radically expanded the then existing treaty design adding 16 new features (out of the 55 coded) to the repertoire of IIAs. What motivated Canada, Mexico and the USA to introduce a radically different treaty design consisting of new exceptions and novel control mechanisms in arbitration?

When NAFTA was concluded in 1992, none of the NAFTA parties had been subject to investment claims. Hence, bounded rationality fails to explain the shift in policy. Were Canada, Mexico and the USA then perhaps negotiating under the shadow of the $A A P L$ claim accepted previously in 1990 as Bayesian learners? Probably not. First, while $A A P L$, with the benefit of hindsight, has been labeled a landmark event, it was much less well known at the time it was decided. ${ }^{108}$ Even in academic circles the $A A P L$ claim was not well known. Strikingly, although the 1992 American Society of International Law Annual Meeting (coinciding with NAFTA negotiations) covered the issue

${ }^{108}$ Appropriately, Pauwelyn calls it a "silent revolution”. Pauwelyn, supra note 26 at 397. 
of investment law and even invited a judge from Sri Lanka (the country targeted by the first investment claim), the case was not mentioned by any of the speakers! ${ }^{109}$ The claim was only popularized and placed in its wider context through Jan Paulsson's seminal article "Arbitration without Privity" five years later. ${ }^{110}$ Second, the $A A P L$ decision was legally controversial at the time it was rendered producing a dissenting opinion. ${ }^{111}$ Hence, it was far from clear that the position adopted by the tribunal's majority would be considered mainstream by the end of the decade. Third, even if the NAFTA negotiators had known about $A A P L$, a legally controversial majority opinion against a developing country on the other side of the Pacific concerning a shrimp farm is unlikely to have triggered a major policy review in the USA and Canada. Forth, while the USA agreed to significant treaty design innovations in NAFTA, it did not subsequently alter its BIT model until a later 2004 reform. ${ }^{112}$ Had the NAFTA policy change been prompted by a sudden realization of ISA's true nature then these changes would have arguably also been integrated into U.S. BITs. The reason for the treaty design shift must thus be found in NAFTA itself and not in $A A P L$.

NAFTA marked the first time in modern investment law that two developing countries with large mutual foreign direct investment (FDI) stocks agreed between themselves on extensive investment protection provisions enforced through investor-state arbitration. ${ }^{113}$ Including an investment chapter

${ }^{109}$ Asoka de Z. Gunawardana \& José E. Alvarez, The Inception and Growth of Bilateral Investment Promotion and Protection Treaties, in PROCEEDINGS OF THE ANNUAL MEETING (AMERICAN SOCIETy OF InTERNATIONAL LAW) 544-555 (1992), http://www.jstor.org/stable/25658683 (last visited Jan 31, 2016).

${ }^{110}$ Paulsson, supra note 48.

111 Asian Agricultural Products Ltd. v. Republic of Sri Lanka, ICSID Case No. ARB/87/3, Dissenting Opinion of Samuel K.B. Asante (June, 15 1990).

${ }^{112}$ See U.S. case study below.

${ }^{113} \mathrm{~J}$. Anthony VanDuzer, Investor-state dispute settlement under NAFTA Chapter 11: The shape of things to come, 35 CAN YB INTL L 263, 266 (1997); Daniel M. Price, Overview of the NAFTA Investment Chapter: Substantive Rules and Investor-State Dispute Settlement, An, 27 InT. LAWYER 727, 736 (1993); Mark Clodfelter, US State Department Participation in International Economic Dispute Resolution, 42 TEX REV 1273, 1283 (2001) ("The United States, and for that matter Canada and Mexico, took a very big step into the unknown when they signed on to Chapter $11 \ldots$ Even though the United States has been party to a fair number of BITs, which have arrangements resembling Chapter 11, we have never done so with states that have so much investment in our territory"). Canada and the U.S had already concluded an FTA with investment chapter in 1988. However, that earlier agreement had only contained a rudimentary set of provisions and no ISA. Jean Raby, The Investment Provisions of the Canada-United States Free Trade Agreement: A Canadian Perspective, 84 AM. J. INT. LAW 394, 395 (1990) ("Canada is the big winner on investment ...Canada's ability to regulate and control American direct investment has not been drastically reduced by the FTA"). 
in an FTA was not strictly new. Already the Canada-USA Free Trade Agreement signed in 1988 had an investment chapter albeit without investorstate arbitration. ${ }^{114}$ The novelty in NAFTA was then the integration of an ISA clause, which, even though it was presumably targeted primarily at the newcomer Mexico, could also be used against Canada or the United States.

In contrast to most investment relations underlying IIAs that were marked by decidedly asymmetric capital flows from a (developed) source to a (developing) destination country, ${ }^{115}$ investment relations in NAFTA were characterized by considerable bi-directional investment flows and mutual FDI stock. ${ }^{116}$ This novel symmetry in investment relations had an impact on treaty design. Negotiators could not any longer ignore the possibility that Canada or the United States would become targets for investment claims. What then emerged was an exception structure and enforcement architecture, which mitigated the impact of investment arbitration claims. The NAFTA treaty design revolution was thus about anticipating rather than reacting to investment claims.

If that assessment of the policy shift underlying NAFTA is correct, then an important corollary follows. While empirical research shows that developing countries may have long underestimated the liability risks of ISA enforcement, ${ }^{117}$ at least some developed states were arguably aware of them, but up to NAFTA considered their likelihood too remote. Empirical research suggests that developed countries are chiefly responsible for treaty design outcomes by furnishing and insisting on their treaty template as basis for negotiations. ${ }^{118}$ Put differently, developed countries are the system's rule makers while developing countries are its rule-takers. As long as investment flows were asymmetrical the likelihood for developed states to be sued by a developing country investor were extremely remote. ${ }^{119}$ Hence, developed

\footnotetext{
${ }_{114}^{114}$ Raby, supra note 114.

115 Jeswald W. Salacuse \& Nicholas P. Sullivan, Do BITs Really Work: An Evaluation of Bilateral Investment Treaties and Their Grand Bargain, 46 HARV. InT. LAW J. 67, 77 (2005). According to them "a BIT between a developed and a developing country is founded on a grand bargain: a promise of protection of capital in return for the prospect of more capital in the future." See also, Jeswald W. Salacuse, BIT by BIT: The Growth of Bilateral Investment Treaties and Their Impact on Foreign Investment in Developing Countries, 24 InT. LAWYER ABA 655, 663 (1990).

${ }^{116}$ Alan M. Rugman, Multinationals and Canada-United States Free Trade 12 (1990).

${ }^{117}$ Poulsen, supra note 46.

${ }^{118}$ Alschner and Skougarevskiy, supra note 6.

119 PATRICK JUILlard, L'ÉVOLUTION DES SOURCES DU DROIT DES INVESTISSEMENTS 108 (1994); F. A. Mann, British Treaties for the Promotion and Protection of Investments, 52 BR. YEARB. InT. LAW 241-254, 241 (1982).
} 
countries could comfortably live with a strong ISA enforcement without simultaneously lowering protection or adding voice to the arbitration procedure because they were not likely to be the target of the more intrusive law enforcement. ${ }^{120}$ This changed with NAFTA. As symmetry entered investment relations so did the safeguards to mitigate the anticipated effect of investment arbitration through additional exceptions and arbitration control mechanisms that we identified in Table 1. Hence, while the U.S. and Canada may not have fully foreseen all implications of ISA, they, in contrast to (most) developing countries, did not need to learn from investment claims, but had already understood the broad liability implications of ISA.

2. Innovation in the early 2000: Refinements based on case law developments rather than learning from claims

While NAFTA innovations may not have been caused by then existing investment claims can the period 4 innovations from the early 2000s be explained as reactions to investment claims? Poulsen highlights that "it wasn't until around 2002 that developing countries had clear information available that BITs' ability to expose host states to liabilities was very real and concrete, rather than merely vague and abstract." ${ }^{\prime 21}$ By that time also developed countries had become the targets of investment claims. The late 1990s had seen a wave of NAFTA claims being launched against the U.S. and Canada and the first set of awards, such as Mondev v U.S. and S.D. Myers v Canada, were handed down in 2002. ${ }^{122}$ In short, while states may not have taken notice of the $A A P L$ claim, they could be expected to react to the wave of claims that had materialized by the early 2000s as Bayesian learners or had become targets of investment claims themselves potentially triggering a bounded rational response. Although the timing of period 4 innovations coinciding with the rise of claims could suggest as much, their substance paints a different picture.

If states had been surprised by an unexpected surge of investment claims and sought to correct their earlier mistakes by reining in the treaties'

${ }^{120}$ In that vein, former U.S. BIT negotiator Alvarez explains: "The United States did not need to worry very much about adapting its laws or practices, ... because, given the oneway flow of capital between the relevant parties, it was extremely unlikely that investors from any of those countries would emerge in any significant presence in the United States, much less be in a position to file a complaint against the United States for a breach of the BIT." José E. Alvarez, The Evolving BIT, TRAnSNATL. DispUTE MANAG., $3(2010)$.

${ }^{121}$ POULSEN, supra note 103 at 203-4.

122 Mondev International Ltd. v. United States of America, Award. ICSID Case No. ARB(AF)/ 99/2 (Oct 11, 2002); S.D. Myers, Inc. v. Canada, Second Partial Award (Oct. 21, 2002). 
propensity to unduly restrict policy space, we would expect states to react with period 3 features as we have seen them in the early 1990s: new exceptions, means of inter-state intervention into the arbitral process and limitations on the access and compensation arbitration can provide to investors. These changes gave birth to a veritably new type of investment treaty design and arbitration.

Period 4 innovations, in contrast, constitute targeted refinements. Some of these refinements, such as new provisions on preliminary objections, also make it easier for states to defend against investment claims. Yet, the bulk of innovation is not targeted at correcting the architecture of investment treaties as such, but is rather aimed at guiding its use and preventing its abuse. As we will show in Section 6, devoid of the context supplied by arbitral practice and jurisprudence, these novel inclusions, such as a clarification that MFN does not apply to dispute settlement clauses, would hardly make sense as tools to limit the impact of investment claims. Thus, in Section 6 below we will argue that these innovations are to be understood not as reactions to unanticipated investment claims, but to unanticipated investment case law.

\section{Treaty design diffusion and investment claims}

While investment claims cannot convincingly be said to have caused most of the treaty innovation from the 1990s onwards, did they play a significant role in their diffusion? As this sub-section will show, the impact of investment claims on the diffusion of treaty design changes is actually much smaller than the vivid, well-known example of the U.S. changing its BIT design in the wake of claims suggests. Two other processes have instead decisively shaped the diffusion of treaty design change: (1) bi-directional causation and (2) the domestic policy environment, which determines whether path dependency and bureaucratic inertia are heeded or overcome.

\section{Bi-directional causation}

One of the reasons why econometric models face difficulty in isolating the impact of investment claims on treaty design is that causality can work both ways, a phenomenon also known as reverse or bi-directional causality: investment claims can cause treaty design changes and treaty design changes can cause investment claims.

NAFTA is a case in point. Quite counter-intuitively, NAFTA - a treaty designed to fend off investment claims through more exceptions and procedural controls - has been instrumental in facilitating the surge of investment claims. In the decade between $A A P L$ in 1987 and 1997 only 11 
investment cases were filed. ${ }^{123}$ All but two of them were brought under different BITs, involved different parties and were defended and heard by different counsels and arbitrators. Moreover, half of these early cases were settled not resulting in awards. Put differently, by 1997 investment arbitration hardly existed as a field. Then between 1997 and 1999 a total of 31 claims were submitted - 10 of which were brought under NAFTA.

NAFTA by itself did not cause these claims. Yet, it provided a necessary if not sufficient enabling environment for their proliferation. First of all, in the late 1990s a group of inventive and entrepreneurial North American lawyers "discovered" NAFTA's potential for opening a new avenue of litigation. One of these NAFTA pioneers was Canadian lawyer Barry Appleton who in June 1994 published "Navigating NAFTA: A Concise User's Guide to the North American Free Trade Agreement" 124 and in 1997 filed one of the first NAFTA cases Ethyl Corporation v Canada. In the following three consecutive years, Appleton represented claimants in S.D. Myers (1998), Pope \& Talbot (1999) and UPS (2000) against Canada. ${ }^{125}$ NAFTA thus enabled industrious lawyers, like Appleton, to establish a new area of litigation practice.

Second, NAFTA Chapter 11's development into an area of litigation triggered a migration of prestigious practitioners attracted by the new professional opportunities. As a need for competent NAFTA arbitrators arose, high-level adjudicators from other international tribunals, like Stephan Schwebel, former judge and president of the International Court of Justice (ICJ), joined the bourgeoning field. ${ }^{126}$ At the same time former NAFTA negotiators like Daniel Price, or state legal advisers, such as Bart Legum, shifted from the public to the private sector beginning to act as counsels in NAFTA investment disputes. ${ }^{127}$ This migration into NAFTA investment arbitration practice not only brought further expertise to the field but also added to its appeal for aspiring young lawyers both in North America and

${ }^{123}$ This information is based on UNCTAD's database on investor-state disputes, available at http://investmentpolicyhub.unctad.org/ISDS.

${ }^{124}$ Barry Appleton, Navigating NAFta: A Concise User's Guide to the North AMERICAN FREE TRADE AGREEMENT (1994).

${ }^{125}$ See Appleton's firm website at http://www.appletonlaw.com/experience.html.

${ }^{126}$ Stephan Schwebel was a judge at the ICJ between 1981 and 2000 and its president between 1997 and 2000. He was first appointed as NAFTA arbitrator by the respondent in Mondev International Ltd. v. United States of America (ICSID Case No. $\mathrm{ARB}(\mathrm{AF}) / 99 / 2$ ). He has since served on more than a dozen investment arbitration tribunals.

${ }^{127}$ Daniel Price was a long term Partner at Sidley Austin's Sidley Austin LLP International Trade and Dispute Resolution Section before joining the firm to work independently as arbitrator, see http://danielmpricepllc.com. Bart Legum is the head Denton's Investment Treaty Arbitration Practice, see http://www.dentons.com/en/barton-legum. 
abroad to become an investment arbitration practitioner.

Third, the surge of NAFTA Chapter 11 claims from the 1990s onwards was also a key factor in establishing investment arbitration as a field of study. Early NAFTA cases sparked vivid academic debates drawing scholars and their students to this new field of law. A search for academic journal articles on heinonline using "NAFTA Chapter 11" and "investment arbitration" as key words between 1992 and 2012 illustrates this: NAFTA Chapter 11 initially received more academic attention than investment arbitration, yet starting in the mid-2000s investment arbitration eclipsed the former in academic publications. ${ }^{128}$

Finally, NAFTA made investment arbitration known to the North American general public. Inspired by controversies surrounding Chapter 11's implications for environmental or health policy, non-governmental interest groups took positions on (and often against) elements of Chapter 11 contributing to public awareness on investment arbitration. ${ }^{129}$ Furthermore, media coverage on investment arbitration increased as programs like the 2002 PBS documentary "Trading Democracy" critically reviewed early NAFTA cases. ${ }^{130}$ At a time when few non-experts knew about investment arbitration in Europe, the issue had already triggered public debates in North America. In short, NAFTA was the best promotion campaign investment arbitration could have gotten and was therefore instrumental in setting the stage for the ensuing proliferation of investment claims.

NAFTA's role in shaping the early days of investment arbitration had an impact on the subsequent diffusion of its treaty design elements, which surged from the mid-2000s onwards. Of the 10 NAFTA claims submitted between 1997 and 1999, 9 resulted in awards. NAFTA decisions were thus among the first rendered by arbitral tribunals shaping the foundation of this early field of law. The Metalclad, ${ }^{131}$ Loewen $^{132}$ or Methanex ${ }^{133}$ awards have become

\footnotetext{
${ }^{128}$ While in 1992, only 2 academic articles were published on NAFTA Chapter 11 and 20 on investment arbitration, NAFTA scholarship overtook general investment arbitration writing in 1999 peaking in 2005 with 148 academic publications as opposed to 129 articles on investment arbitration. Then trends reversed and in 2010 twice as many and in 2012 even six times as many articles on investment arbitration were published than on NAFTA Chapter 11. These numbers were retrieved based on a key word search for "investment arbitration" and "NAFTA Chapter 11" on heinonline in December 2015.

${ }^{129}$ M. Kinnear \& R. Hansen, The Influence of NAFTA Chapter 11 in the BIT Landscape, 12 UC DAVIS J INTL POL 101, 106-109 (2005).

${ }^{130}$ More information available at: http://www.pbs.org/now/politics/tradingdemocracy.html.

${ }^{131}$ Metalclad Corporation v. The United Mexican States, ICSID Case No. ARB(AF)/97/1, Award (Aug. 30, 2000).
} 
"classics" in today's investment arbitration. Moreover, until 2013 NAFTA was the most litigated treaty with over 50 disputes filed. ${ }^{134}$ As a result, NAFTA provisions are among the most interpreted and commented treaty elements in the IIA universe, which adds to their predictability. It is thus easy to see why NAFTA innovations spread as investment claims rose: if countries wanted to change their treaty design to mitigate the - for many states - unforeseen impact of investment claims, they could turn to NAFTA as an off-the-shelve alternative to their existing practice that had been tried and tested in actual cases. The use of NAFTA in early claims thus created a path dependency as countries opted into language tested and clarified through arbitration.

In conclusion, we are confronted with a causality loop between investment claims and the diffusion of NAFTA design elements: NAFTA provided an enabling environment that led to investment claims and these investment claims, in turn, entrenched NAFTA's position as trusted treaty design alternative for countries wishing to mitigate the impact of investment claims.

2. Stories of (non)diffusion: U.S., Canada, Germany and Japan

Yet, what exactly triggers a country's decision to engage in innovation by opting into the NAFTA treaty design elements? Is it, as the above-presented theories suggest, a response to being hit by an investment claim or learning from others' experience with arbitration? Or are there other elements at play? To answer that question we will investigate the changing BIT practice of the U.S., Canada, Germany and Japan. ${ }^{135}$ These four countries share similar characteristics - they are wealthy developed democracies with large stocks of outward and inward investments. Yet, their experience with investment claims and the treaty design changes they introduce differ starkly making them interesting case studies. The U.S. and Canada were subject to investment claims early on, yet while the U.S. changed the design of its treaties only after becoming a respondent to investment claims, Canada had integrated many NAFTA features into its BITs already prior to its first investment claim. Germany was also hit by investment claims early on, but did not alter its treaties subsequently. Finally, Japan was never a respondent in an investment

${ }^{132}$ Loewen Group, Inc. and Raymond L. Loewen v. United States of America, ICSID Case No. ARB(AF)/98/3, Award (Jun. 26, 2003).

${ }^{133}$ Methanex Corp. v. United States, UNCITRAL, Partial Award (Aug. 7, 2002) and Final Award of the Tribunal on Jurisdiction and Merits (Aug. 3, 2005).

${ }^{134}$ After 2013, NAFTA became second place as the Energy Charter has attracted doubledigit numbers of new cases per year.

135 We focus exclusively on BITs (rather than IIAs generally) to ensure comparability between the four different cases as Germany has not signed any Free Trade Agreements with investment chapters on its own. 
dispute, yet it remodeled its treaties significantly after 2002 .

We purposefully focus on developed countries rather than developing countries in these case studies. Although investment claims may also change the policy preferences of developing countries, this change is less likely to translate into actual treaty design adjustments given the asymmetric rule-takervs-rule-maker dynamics prevalent in the IIA universe. ${ }^{136}$ Whereas developed countries have the bargaining power to translate a change of their policy preferences into a change in the design of the treaties they negotiate, ${ }^{137}$ developing countries are less able to affect negotiation outcomes and thus more likely to respond to changing preferences through unilateral acts halting their investment treaty programs, like Argentina, ${ }^{138}$ denouncing selected BITs, like South Africa or Indonesia, ${ }^{139}$ or exiting the system altogether, like Bolivia or Ecuador. ${ }^{140}$

The review of these developed countries case studies will show that it takes more than investment claims for treaty design elements to diffuse. As Puig points out, day-to-day investment policy is made in bureaucratic structures prone to inertia and a status quo bias. ${ }^{141}$ Policy makers can break with path dependency and engage in innovation, but whether they do it or not depends on factors other than investment claims including, but not limited to, the streamlining of foreign investment policy, changing national or international economic policy agendas, or how information on investor-state arbitration is disseminated and processed in a country.

\footnotetext{
${ }^{136}$ Alschner and Skougarevskiy, supra note 6.

137 Some developing states, such as India, have also revised their model agreements in anticipation of future investment treaty (re-)negotiations. At the time of this writing, however, no investment treaty has been negotiated on that template. Developed countries' BIT practice thus constitutes the most reliable source for tracing the impact of claims on the design of concluded BITs.

138 Argentina signed its last BIT in March 2001 with the Dominican Republic (never ratified) shortly after the first investment claim was decided against Argentina in November 2000 (Compañia de Aguas del Aconquija S.A. and Vivendi Universal S.A. v. Argentine Republic, ICSID Case No. ARB/97/3, Award (Nov. 21, 2000).

139 South Africa begins withdrawing from EU-member BITs, Investment Treaty News (Oct. 30, 2012), available at: https://www.iisd.org/itn/2012/10/30/news-in-brief-9/; Indonesia to terminate more than 60 bilateral investment treaties, Financial Times (Mar. 26, 2014) available at: https://next.ft.com/content/3755c1b2-b4e2-11e3-af92-00144feabdc0.

${ }^{140}$ UNCTAD, Denunciation of the ICSID convention and BITS: Impact on investor-state claims, UNCTAD IIA ISSUE NOTE (2010).

141 The role of bureaucratic inertia is also addressed in Sergio Puig, Does Bureaucratic Inertia Matter in Treaty Bargaining-Or, toward a Greater Use of Qualitative Data in Empirical Legal Inquiries, 12 ST. CLARA J INTL L 317 (2013).
} 
a. United States - Treaty design change after investment claims

The experience of the United States is the primary showcase for a strong impact of investment arbitration on rule making. Soon after it faced its first investment claim under NAFTA, Loewen in $1998,{ }^{142}$ the U.S. halted the negotiation of new investment treaties in 1999 and initiated a policy review. The outcome of that review was the 2004 model BIT, which integrated NAFTA period 3 innovations into U.S. BITs and reacted to early arbitral case law by including targeted period 4 innovations. ${ }^{143}$ This radical change in U.S. policy following investment claims can be traced in Figure 6.

At the same time, the conventional narrative focusing on the differences between pre- and post-2004 BITs misses the mark. ${ }^{144}$ What investment claims did was to challenge the wisdom of having separate treaty design preferences for BITs and FTAs. After the innovations of NAFTA, the United States continued to use its prior model to negotiate BITs leading to a disconnect between its FTA investment policy and its BIT policy. Investment claims revealed this disconnect to be untenable.

${ }^{142}$ Loewen Group, Inc. and Raymond L. Loewen v. United States of America, ICSID Case No. $\operatorname{ARB}(\mathrm{AF}) / 98 / 3$.

143 G. Gagne \& J.F. Morin, The Evolving American Policy on Investment Protection: Evidence from Recent FTAs and the 2004 Model BIT, 9 J. INT. ECON. LAW 357-382 (2006); Vandevelde, supra note 3.

${ }^{144}$ See e.g. Vandevelde, supra note 3. 
Figure 6: U.S. BIT practice and its investment claims experience

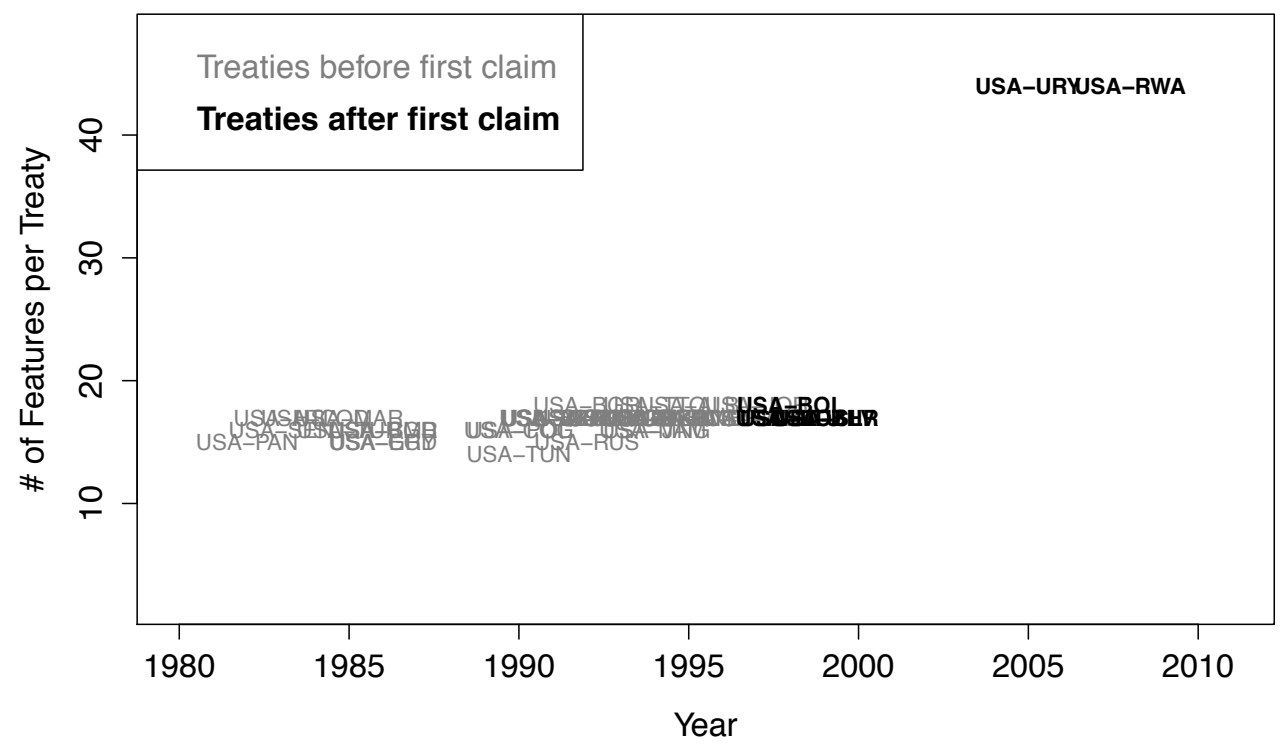

Note: The figure displays U.S. BITs based on their year of signature and total score of coded features from the categories of protection, exception and arbitration. Each treaty is color-coded based on whether it was signed before or during the year of the first investment claim (grey) or after that date (black).

First of all, the investment claims led the U.S. as Bayesian learner to reevaluating the likelihood of being a target in investment arbitration. As we explained above, investment flows and stocks were symmetric under NAFTA. This may have induced the U.S. to consider claims more likely under NAFTA warranting policy space safeguards. Yet, no equivalent symmetry existed in the relations between the U.S. and its developing country BIT partners in the 1990s. In light of asymmetric investment flows, investment claims against the U.S. seemed remote under BITs and policy space safeguards unnecessary from a U.S. perspective. ${ }^{145}$ Since the late 1990 s, however, the risk of being sued arguably increased even in asymmetric investment relations. The expansive interpretations of investment treaties including of the notions of investor and investment combined with the fungible notion of capital, strategic corporate restructuring and more awareness of investment arbitration have made investment claims under any treaty more likely. ${ }^{146}$ As the U.S. feared to

${ }^{145}$ Alvarez, supra note 121 at 3.

146 Several authors have pointed out that today more than one investment treaty may govern a single investment transaction. STEPHAN W. SCHILL, THE MultilateralizATION OF INTERNATIONAL INVESTMENT LAW 197-240 (2009); B. Legum, Defining Investment and Investor Who is Entitled to Claim?, 22 ARBITR. INT. 521 (2006). 
become the target of investment claims, the differentiated approach in BITs and NAFTA was abandoned in favor of a one-size-fits all policy that contained the greater safeguards for policy space initially developed for NAFTA.

Second, U.S. may have also reacted as bounded rational learner. The long held belief that the U.S.' political and legal structures were immune to challenge under investment treaties and that ISA would primarily be used against developing countries with a poor rule-of-law record was shattered by the late $1990 \mathrm{~s}$ as the U.S. itself became a target of investment claims. ${ }^{147}$ Although the U.S. did not loose any of its early investment cases, the use of ISA to challenge U.S. legislations corrected its optimism bias creating a heightened awareness that any country irrespective of the quality of its domestic legal system could become a target for ISA claims.

Third, and perhaps most importantly, the critical domestic debate triggered by NAFTA claims put pressure on U.S. policy-makers to "do something". 148 The bipartisan 2002 Trade Promotion Authority legislation then marked a turning point in U.S. investment policy making stating that "United States investors in the United States are not [to be] accorded lesser rights than foreign investors in the United States" and listing several ways in which investor-state arbitration was to be improved. ${ }^{149}$ Congress thereby largely mandated a realignment of U.S. BIT practice with NAFTA treaty design and its lessons learnt.

In conclusion, in the case of the U.S., investment claims prompted a change in the country's investment policy. Yet, this change was not one from the 1994 U.S. model BIT to the 2004 model. Instead, it was an alignment of its FTA and BIT practice. The impact of investment claims thus resulted in an integration of NAFTA design elements into BITs rather than a complete reinvention of U.S. practice as a comparison of between pre- and post-

${ }^{147}$ Alvarez, supra note 121 at 3 ("The United States could afford to assume that its laws and practices were already consistent with the minimal standards contained in its BITs."); Prior to the rise of investment claims against Canada and the U.S., a widely held assumption was that investment claims would only be launched against developed countries, since developed countries already offered adequate protection to foreign investors. See e.g. Voss stating that "An active investment protection and promotion policy exists only in relations with Third World countries. In all the industrial countries there is a comparable and sufficiently stable protection framework so that investments flow freely to their optimal economic use." Jürgen Voss, The Protection and Promotion of Foreign Direct Investment in Developing Countries: Interests, Interdependencies, Intricacies, 31 INT. COMP. LAW Q. 686-708, 688 (1982).

${ }^{148}$ Kinnear and Hansen, supra note 130 at $106-109$.

${ }^{149}$ Bipartisan Trade Promotion Authority (TPA), Trade Act of 2002, 19 USC s $3801 \mathrm{ff}$. See also Gagne and Morin, supra note 144 at 258-9. 
arbitration BITs would suggest.

\section{b. Canada - Innovation following NAFTA}

The case of Canada is somewhat different, because Canada already incorporated the lessons learned from NAFTA into its BITs making reducing the later impact of investment claims on its treaty design. The evolution of Canadian practice can be traced in Figure 7. Canada entered the BIT universe relatively late signing its first BIT in 1989 with Russia. At that time, Canada followed a BIT model heavily influenced by the 1967 OECD Draft Convention on the Protection of Foreign. ${ }^{150}$ Early Canadian BITs were thus short and simple treaties similar in design to BITs of European countries that had equally adopted templates modeled on the OECD draft. ${ }^{151}$ Following the conclusion of NAFTA in 1992, however, the treaty design of Canadian BITs changed drastically as innovations from NAFTA's Investment Chapter 11 were introduced into its new BITs (period 3 innovation). ${ }^{152}$ Why Canada chose to alter its BIT design is unclear. Bounded rational learning from investment claims can be excluded as cause since claims only hit Canada later. ${ }^{153}$ Nor is symmetry of investment flows a credible explanation as the design template was applied irrespective of the investment flows or stock of Canada's negotiation partner. ${ }^{154}$ The most persuasive explanation is probably that decision makers considered NAFTA to constitute an update of Canada's investment policy and asked the relevant ministry to streamline future Canadian IIAs with NAFTA. Canadian treaty practice thus displays a strong coincidence in time between innovation and diffusion.

\footnotetext{
${ }^{150}$ Kinnear and Hansen, supra note 130 at 103.

${ }^{151}$ SCHILL, supra note 65 at 35-6.

152 James McIlroy, Canada's New Foreign Investment Protection and Promotion Agreement, 5 J. World InVEST. TRADE 621-646, 623-9 (2004).

${ }^{153}$ The first claim was Ethyl Corporation $v$ The Government of Canada, UNCITRAL. For the subsequent complaints see http:/www.international.gc.ca/trade-agreements-accordscommerciaux/topics-domaines/disp-diff/gov.aspx?lang=eng.

${ }^{154}$ Canada's negotiating partners included a range of small countries with low levels of FDI in Canada such as Armenia and Latvia and minute risks of ISA claims.
} 
Figure 7: Canadian BIT practice and its investment claims experience

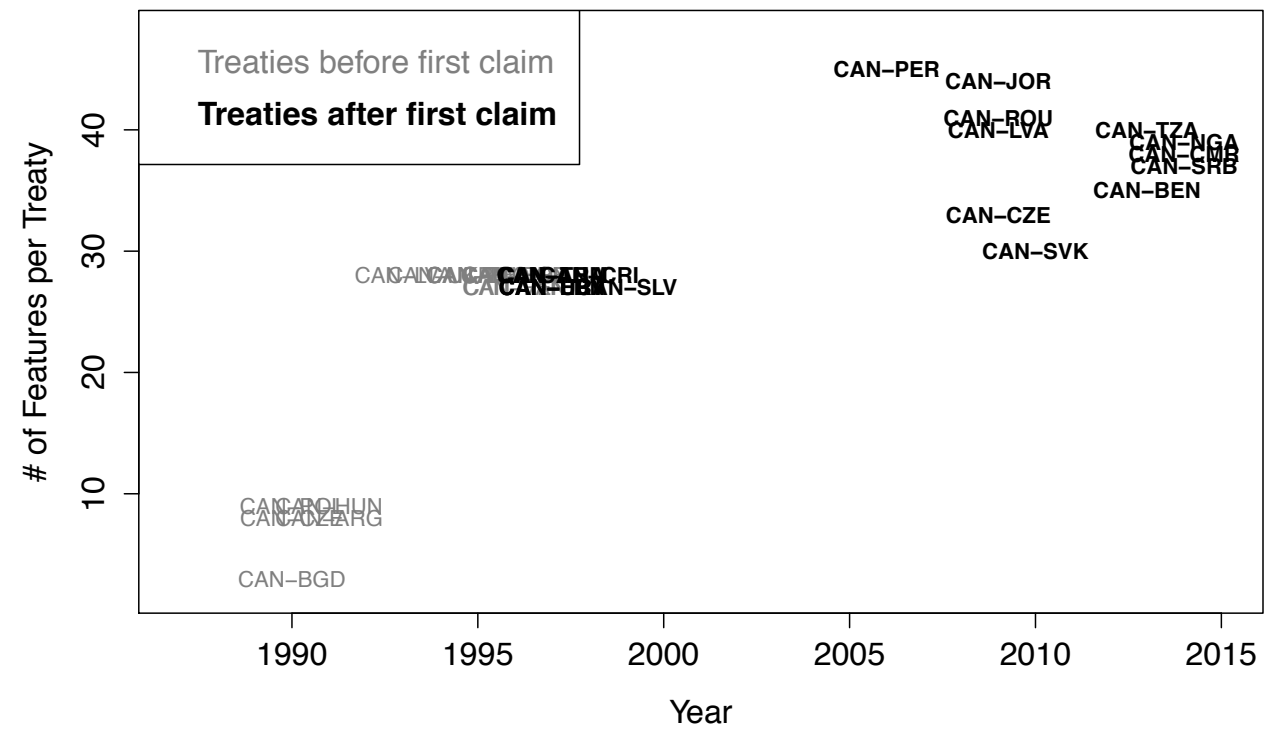

Note: The figure displays Canadian BITs based on their year of signature and total score of coded features from the categories of protection, exception and arbitration. Each treaty is color-coded based on whether it was signed before or during the year of the first investment claim (grey) or after that date (black).

The later impact of claims on investment treaty design in Canadian BIT practice was therefore less significant. The first claim against Canada was launched in 1997. Canada continued to sign new BITs until 1999, before it halted its program for five years. Canada then concentrated its efforts on defending existing claims not concluding any new IIAs. After evaluating how Chapter 11 had performed in "real life", Canada did not abandon NAFTA treaty design. Instead, its 2004 model BIT, as commentators agree, closely follows NAFTA practice. ${ }^{155}$ In addition, it included period 4 innovations in its model BIT, which enshrine refinements and lessons learned from NAFTA litigation. Figure 7 allows us to put these changes into perspective: the gap between early Canadian treaties modeled on the OECD practice is much wider than the gap between its BITs signed in the mid 1990s and those concluded in the 2000s. Hence, while case law helped to refine NAFTA design architecture, the real innovation in Canada's practice had taken place ten years earlier.

The case thus not only shows that innovation in BITs can take place prior to claims, with Canada updating its BIT template following NAFTA, but also

155 Celine Levesque, Influences on the Canadian FIPA Model and the US Model BIT: NAFTA Chapter 11 and Beyond, 44 CAN. YEARB. INT. LAW 249 (2006); Kinnear and Hansen, supra note 130 at 110. 
that claims, can further entrench a country in its pre-claims architecture rather than producing radically innovation, since Canada deepened its commitment to a NAFTA design architecture albeit refined through case law induced clarifications.

\section{c. Germany - Business as usual in spite of investment claims}

In stark contrast to these North American reactions to investment claims, Germany's BITs were unaffected by the rise of investment cases. Germany is credited with having invented the BIT signing the first of these agreements with Pakistan in 1959. While the terms of its treaties have been slightly reformulated over time, the structure of German treaties has remained remarkably constant. ${ }^{156}$ Figure 8 traces this consistency over time.

Figure 8: The German BIT practice and its investment claims experience

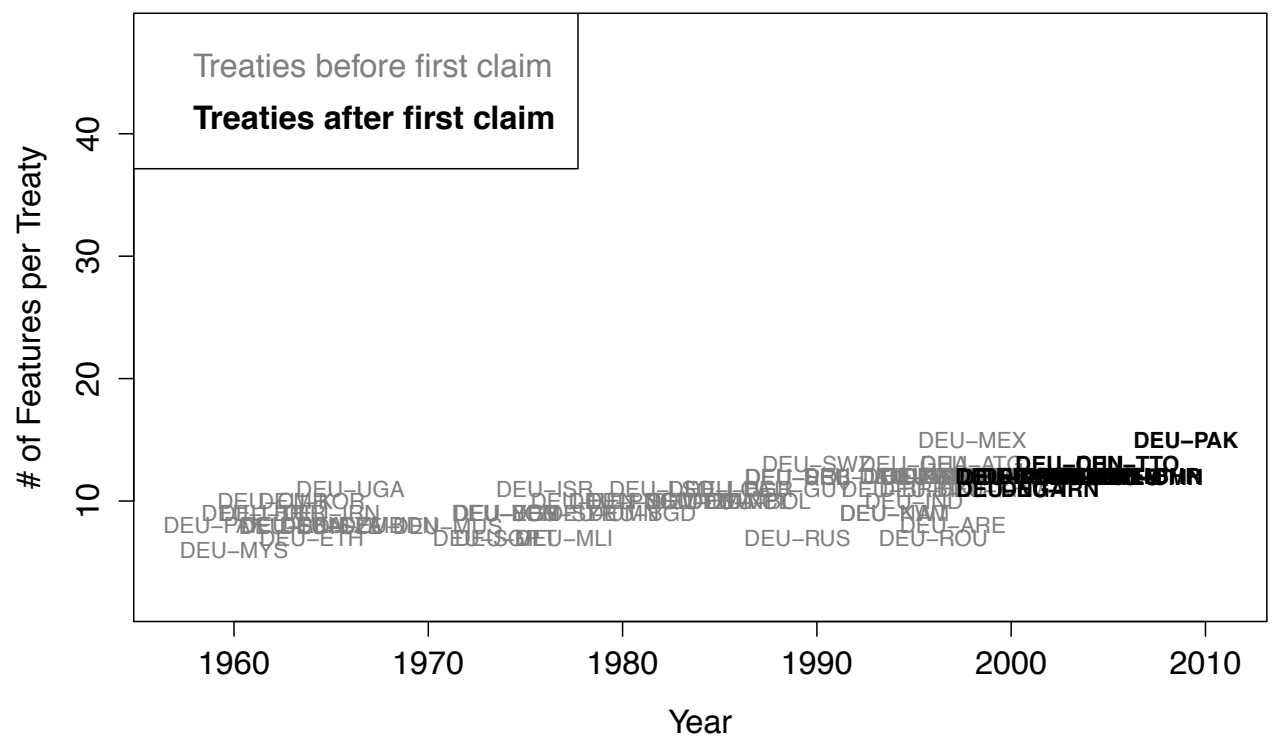

Note: The figure displays German BITs based on their year of signature and total score of coded features from the categories of protection, exception and arbitration. Each treaty is color-coded based on whether it was signed before or during the year of the first investment claim (grey) or after that date (black).

${ }^{156}$ The structure of its treaties is so similar that a 2013 commentary on the 2009 German model BIT cross-references every provision to the corresponding clause in the 1959 Germany-Pakistan BIT. See Rudolf Dolzer \& Yun-I Kim, Commentary on Germany's Model BIT (2009), in Commentaries on Selected Model Investment Treaties (Chester Brown \& Devashish Krishan eds., 2013). 
At the same time, Germany, like the United States, has been the target of investment claims. In 2000, Indian investor Ashok Sancheti initiated arbitration pursuant to the Germany-India BIT. ${ }^{157}$ Eight years later, the Swedish company Vattenfall filed an arbitration claim pursuant to the Energy Charter challenging environmental permit delays and, ultimately, denials by the city of Hamburg that impeded the construction of a coal-fired power plant. ${ }^{158}$ Both cases were settled. A third investment claim also brought by Vattenfall relating to Germany's withdrawal from nuclear energy is still pending. 159

How can we explain the difference between investment claims' impact on the United States as opposed to Germany? The key difference between them lies in the way information relating to investment claims was handled. German cases have been dealt with under a veil of secrecy, while in the U.S. a culture of transparency had emerged early on.

Until recently arbitration rules did not mandate the publication of awards and sometimes did not even require the disclosure of claims. It therefore depended on the attitudes of respondent governments to what extent investment claims' information entered the public domain. In NAFTA, the United States provided for the possibility to make awards public (Annex 1137.4) and in subsequent decisions in 2001 and 2003 institutionalized public access to dispute settlement information. ${ }^{160}$ This transparency introduced investment arbitration claims into the public sphere and thereby fueled the political debate, which as described above, led to the treaty design changes of the 2004 U.S. model BIT. In Germany, in contrast, investment arbitration was long kept below the public or political radar. German BITs did not mandate the publication of dispute settlement information and the German Ministry of Economics, in charge of negotiating BITs and defending BIT claims, kept such information under wraps. The Ashok Sancheti v. Germany claim of 2000, for instance, was only revealed in 2008 through the investor and upon an inquiry by IAReporter. ${ }^{161}$ The terms of its settlement still remain unknown. Similarly, the first Vattenfall case was handled in secrecy until the terms of the

${ }^{157}$ IAReporter, Court documents reveal that Indian investor filed treaty claim against UK government in 2006; Foreign Office views UNCITRAL-based disputes as confidential and declines to disclose their existence, Volume 1, No. 18, (Nov. 25, 2008), available at: http://www.iareporter.com/downloads/20100107_13/download (last visited Feb. 2, 2015).

158 For a listing of German cases see http://www.german-investment-treatydisputes.de/Home/Index/de (last visited Feb. 2, 2015).

${ }^{159}$ Vattenfall $A B$ and others v. Federal Republic of Germany, ICSID Case No. ARB/12/12.

${ }^{160}$ See note 213 and accompanying text below.

${ }^{161}$ IAReporter, supra note 157. 
settlement were disclosed in August 2010 ${ }^{162}$ Indeed, even on the inter-agency level, other ministries were scarcely involved in BIT matters. ${ }^{163}$ The paradox result was that in Germany, the country that had invented the BIT, ISA claims were almost completely unknown outside of the Ministry of Economics, while in the United States, a latecomer to BITs, ISA claims had been known to and hotly debated by politicians and civil society alike.

The situation in Germany changed drastically in the early 2010 s. ${ }^{164}$ First, in 2009, competency for the conclusion of investment treaties shifted from the EU member states to the EU Commission with the entry into force of the Lisbon treaty. ${ }^{165}$ Taking the BIT dossier away from the handful of German Ministry of Economics bureaucrats and passing it on to EU officials who were tasked to create a new EU investment policy from scratch under the scrutiny of the EU Parliament placed the issue from the backroom into the forefront of political attention. Second, in 2013 negotiations began on the Transatlantic Trade and Investment Partnership (TTIP), which was to include an investment chapter. Anti-globalization interest groups opposing both the deal and investor-state arbitration seized the occasion and were very successful in mobilizing societal forces against the TTIP to the extent that senior German politicians vouched to veto any deal negotiated by "Brussels" that included investor-state arbitration. ${ }^{166}$ Finally, the second Vattenfall claim challenging

${ }^{162}$ Nathalie Bernasconi, Background paper on Vattenfall v. Germany arbitration, , 2 (2009), https://international-arbitration-attorney.com/wpcontent/uploads/arbitrationlawbackground_vattenfall_vs_germany.pdf (last visited Jul 23, 2016) ("Vattenfall and Germany have refused to comment publicly about the arbitration, so that most aspects of the case are unknown. [...]The German Federal Ministry of Economics and Technology, which is responsible for handling the case, has remained resolutely silent on the matter"). The terms of the settlement can be accessed here: http://www.italaw.com/documents/VattenfallAward.pdf (last visited Feb. 2, 2015).

${ }^{163}$ MAHNAZ MALIK, TIME FOR A CHANGE: GERMANY'S BILATERAL INVESTMENT TREATY PROGRAMME AND DEVELOPMENT POLICY 10 (2006) (inferring a "lack of coordination between the efforts of the German Federal Ministry of Economics and Labour and the German Federal Ministry of Economic Cooperation and Development with respect to investment").

${ }^{164}$ Ralph Alexander Lorz, "Germany, the Transatlantic Trade and Investment Partnership and investment- dispute settlement: Observations on a paradox", Columbia FDI Perspectives, No. 132 (Oct.13, 2014).

${ }^{165}$ See Article 188 C (1) of the Treaty of Lisbon (Article 207 (1) Treaty on the Functioning of the European Union (TFEU).

${ }^{166}$ Reuters, Germany to reject EU-Canada trade deal - Sueddeutsche newspaper, 26 July 2014, available at: http://www.reuters.com/article/2014/07/26/germany-canada-tradeidUSL6N0Q10CS20140726?irpc=932\&ref=browsi (last visited Feb. 2, 2015). See also, Ralph Alexander Lorz, Germany, the Transatlantic Trade and Investment Partnership and investment-dispute settlement: Observations on a paradox, COLUMBIA FDI Perspectives, No. 132 (Oct. 13, 2014). 
the German withdrawal from nuclear energy provided a focal point for ISA critics. Germans have generally been critical of the use of nuclear power and enthusiastically supported the government's decision to phase out nuclear power plants. The widely publicized claim then fueled public awareness of and opposition to ISA. ${ }^{167}$ In the course of a few years, ISA had turned from an issue virtually unknown to one emotionally debated in German politics and civil society.

The fact that Germans really only began in 2014 to read about those "secret tribunals"168 that had been known to American audiences since 2002 then goes a long way in explaining the difference between Germany's and the United States' reaction to investment claims. Absent such knowledge that could have fostered public and political debate, officials in the German Ministry of Economics could proceed with "business as usual" in bureaucratic inertia even after the country was exposed to investment claims in the early 2000s. Therefore, the German case shows that the impact of investment arbitration on rule making depends at least in part on public awareness about investment arbitration and the extent to which this awareness translates into political pressure that prompts decision-makers to overcome with bureaucratic inertia.

\section{d. Japan - Innovation without investment claims}

Japan presents an altogether different picture. The country has never been a respondent in an investment case. Nor has Japan experienced significant public protest and debate on investment arbitration. Nevertheless, Japan is almost at par with the United States and Canada in the conclusion of long and elaborate treaties, which contain widespread exceptions and arbitration safeguards as can be seen in Figure 9. How can we explain this innovation?

Japan began its investment treaty practice in 1977 when it signed its first BIT with Egypt using a short and simple OECD treaty model. On the basis of that template, eight more agreements were concluded over the next 25 years. Then suddenly, in 2002, Japan's treaty practice changed fundamentally and the country started to conclude what Hamamoto and Nottage call a "new

\footnotetext{
${ }^{167}$ Why Vattenfall is taking Germany to court, Vattenfall News Item, 9 Dec 2014, available at http://corporate.vattenfall.com/news-and-media/news/2014/why-vattenfall-is-takinggermany-to-court/ (last visited Feb. 2, 2015).

168 Die Zeit, "Schattenjustiz: Im Namen des Geldes" (Feb. 27, 2014) available at: http://www.zeit.de/2014/10/investitionsschutz-schiedsgericht-icsid-schattenjustiz. Compare that to the 2002 PBS documentary "Trading Democracy" at note 130.
} 
generation" of Japanese agreements. ${ }^{169}$

Hamamoto advances two explanations for this shift in treaty design. ${ }^{170}$ First, earnings from Japanese foreign investment had become a more important item on Japan's commercial policy agenda. While the country had been a lukewarm supporter of BITs before, occasionally accepting offers for the negotiations of BITs from other states, it began to formulate a more activist investment policy agenda in order to become a "mature creditor nation", as a later White Paper of Ministry of Economy, Industry and Trade put it. ${ }^{171}$ Second, prior to 2002 Japan had hoped for a multilateral agreement on investment. As negotiations under the auspices of the OECD failed in the late 1990 s and the issue was scrapped from the WTO agenda in the early 2000s, Japan decided to launch its investment program in earnest in order to build a web of bilateral treaties similar to that of the United States or Europe. ${ }^{172}$

Figure 9: The Japanese BIT practice

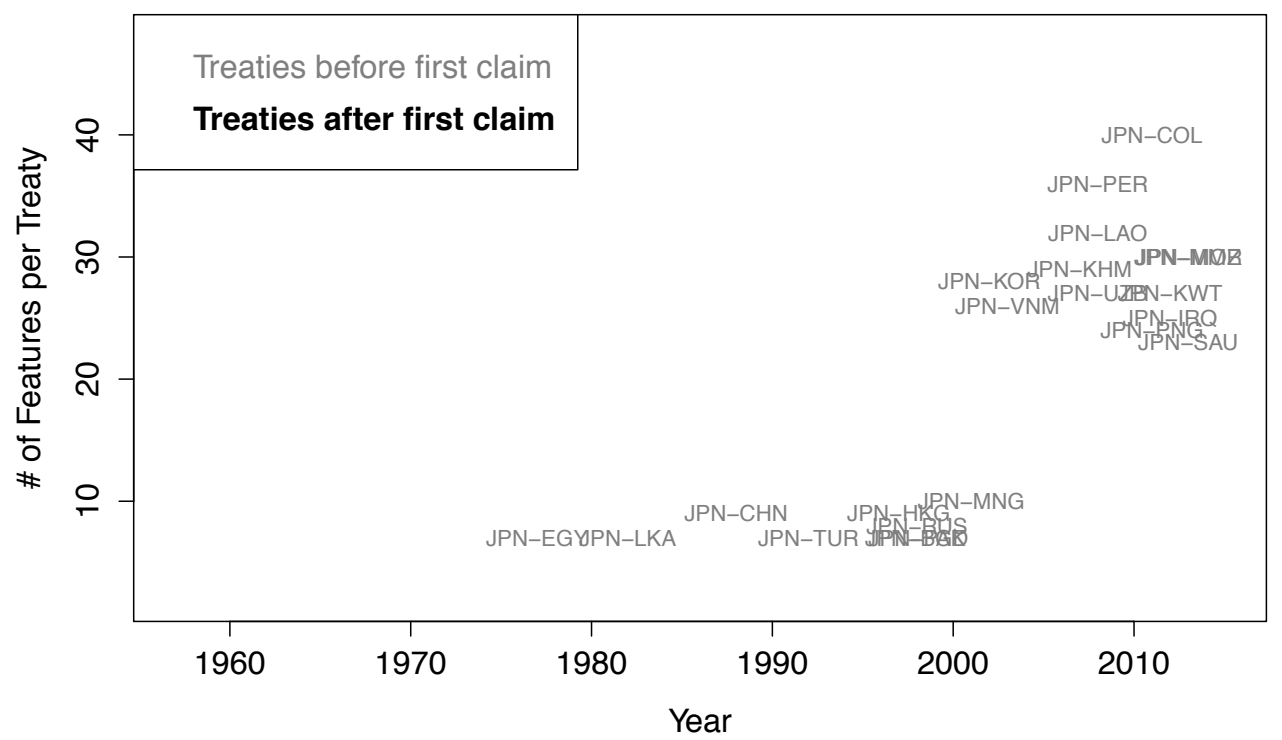

Note: The figure displays Japanese BITs based on their year of signature and total score of coded features from the categories of protection, exception and arbitration. Each treaty is color-coded based on whether it was signed before or during the year of the first investment

169 Shotaro Hamamoto \& Luke Nottage, Foreign Investment In and Out of Japan: Economic Backdrop, Domestic Law, and International Treaty-Based Investor-State Dispute Resolution', SYD. LAW SCH. LEG. STUD. RES. PAP. No 10145 December 2010.

170 Shotaro Hamamoto, A passive player in international investment law: Typically Japanese?, in ForEIGN INVESTMENT AND DisPUTE RESOLUTION LAW AND PRACTICE IN AsIA 53-67 (Luke Nottage \& Vivienne Bath eds., 2011).

${ }^{171} I d$. at $53-54$.

${ }^{172}$ Id. at $54-55$. 
claim (grey) or after that date (black). Since Japan has not yet been respondent in an investment dispute, all its treaties are color-coded grey.

Although Hamamato finds evidence that (later) Japanese BITs were adjusted in response to developments in investment case law (see Section 6 below), his research suggests that investment claims had no impact on the decision to revise Japanese BITs from 2002 onwards. First, Hamamoto points out that foreign investment stock in Japan has been triflingly small making claims against Japan from foreign investors unlikely. ${ }^{173}$ Second, post-2002 Japanese BITs became more rather than less protective of foreign investors than their pre-2002 counterpart. ${ }^{174}$ Instead of limiting Japan's exposure to claims, post-2002 BITs expanded it by adding pre-establishment national and MFN treatment and the prohibition of performance requirements. ${ }^{175}$ Third, together with concluding new BITs, Japan also began signing FTAs with investment chapters. ${ }^{176}$ In its effort to catch up with their North American competitors, Japan followed their lead incorporating NAFTA treaty design elements, such the just mentioned pre-establishment features coupled with other period 3 clauses and period 4 innovations in its IIAs drawing closely from North American treaty language. ${ }^{177}$

In conclusion, while the radical treaty design shift in 2002 coincided with proliferating investment claims, they had little impact on Japan's decision to revise its treaty template. Instead, the country sought to update its treaty practice in light of a changing commercial policy agenda and in response to a transition from multilateral to bilateral international economic diplomacy.

\section{Conclusion: Status quo bias rather than backlash against arbitration}

Our empirical findings suggest that the impact of investment claims is considerably smaller than expected. The vivid and well-known example of the United States updating its BIT design following investment claims seems to be the exception rather than the rule and even there claims merely prompted an alignment between FTA and BIT practice rather than reinvention of investment policy from scratch. The case of Canada and Japan suggests that investment claims sometimes play hardly any role in the diffusion of treaty design innovation. In Canada, claims further entrenched a pre-arbitration design refined through case law induced clarifications. In Japan, domestic and

${ }^{173} \mathrm{Id}$. at 60 .

${ }^{174} \mathrm{Id}$. at $53-54$.

${ }_{176}^{175}$ See the comparative table in Hamamoto and Nottage, supra note 170 at 22-23.

${ }_{177}^{176}$ Id. at 9-10.

177 On this Americanization of investment policy including with respect to Japan see Alschner, supra note 74. 
international economic policy developments were more important drivers for a change in BIT design than claims. Finally, the distinction between the experience of the United States and that of Germany shows that being hit by an investment claim may not be enough to trigger treaty changes: transparency, public awareness and political momentum are needed to translate investment claims into policy responses. Absent such an impact, the tendency of investment negotiators is to continue with "business as usual".

For the current legal debate on how states have responded and how they should respond to the growth of investment claims, the findings of this section provide three major implications.

1. No backlash against investment arbitration

First of all, our findings suggest that the idea that countries react to investment claims by rebalancing their treaties is only partially accurate. The most significant act of rebalancing in the history of investment treaties so far actually pre-dates investment claims: in NAFTA the contracting states anticipated rather than reacted to investment claims designing a new investment treaty architecture, which subsequently diffused widely within the IIA universe. NAFTA itself was instrumental to its own diffusion by giving rise to the first wave of investment claims and awards, which later entrenched its treaty design as tested and tried language that could be taken up by subsequent treaty-makers across the globe. While investment claims did play a part in this diffusion, other factors, such as public knowledge, symmetric FDI flows, changing commercial policies and the interaction of trade and investment disciplines in FTAs, have proven at least as decisive in shaping treaty design outcomes.

The absence of a stronger impact of investment claims can be viewed as a positive sign: we have not seen an opportunistic reaction from states in the face of rising investment claims. Developed countries did not overhaul their treaty design to escape liability once investment claims spread or once they became subject to investment claims. Instead, we see that states faced with investment claims stood their ground and implemented fine-grained innovation in the 2000s. Rather than an opportunistic backlash against arbitration, states thus showcased their strategic long-term commitment to the investment arbitration architecture as first devised in NAFTA and refined thereafter.

2. Status quo bias and anchoring in a pre-ISA architecture

The insight that today's treaty design is still shaped by an architecture that 
pre-dates the surge of investment claims may also be a source of concern. Resisting opportunistic temptation is one thing, sticking to your guns when change is actually needed is quite another. As this section has highlighted, investment law suffers from status quo bias: path dependency dominates over prolific innovation. Treaty design evolution, where it takes place, consists of states opting into and refining tried and tested language rather than trying out something new. This path dependency prevents more radical change even where this change may be on balance beneficial. ${ }^{178}$

Investment claims have exposed some of the IIA system's weaknesses. Mass claims by investors and bondholders in the wake of economic crises, treaty and forum shopping or strategic corporate restructuring and litigation were all issues scarcely contemplated when the pre-ISA architecture was designed. ${ }^{179}$ Add to that the now widespread concerns about inconsistent decisions by tribunals or conflicts of interests among arbitrators. ${ }^{180}$ Seen in this light, the fact that investment claims have only led to an entrenchment and refinement of the original NAFTA architecture rather than triggering more fundamental reforms seems disconcerting.

Does the current proposal by the EU to replace investment arbitration with an investment court constitute a viable alternative breaking with path dependency? Perhaps. Yet rather than focusing on ways how to fix the current system, IIA reform would benefit from first identifying what is wrong with it. Breaking with path dependency is about asking the question: what would the investment regime look like if we could redesign it from scratch today? We need to know what investment treaties are supposed to achieve in our $21^{\text {st }}$ century world, what purpose they serve, before we can determine where we can build on and where we need to depart from established practice.

3. Transparency as pre-condition for policy change

\footnotetext{
${ }^{178}$ For an in-depth discussion of IIA path dependency see, Wolfgang Alschner. Locked-in Language: Historical Sociology and the Textual Path Dependency of International Investment Treaties, in RESEARCH HANDBOOK ON THE SOCIOLOGY OF INTERNATIONAL LAW (Moshe Hirsch \& Andrew Lang, forthcoming).

${ }^{179}$ UNCTAD has consistently documented these novel developments in its annual reports on investor-state arbitration. See e.g. UNCTAD, Recent Developments in Investor-State Dispute Settlement, IIA Issues Note, April 2014 available at: http://unctad.org/en/PublicationsLibrary/webdiaepcb2014d3 en.pdf (last visited Aug. 31, 2016); Recent Developments in Investor-State Dispute Settlement, IIA Issues Note, May 2013 available at: http://unctad.org/en/PublicationsLibrary/webdiaepcb2013d3_en.pdf (last visited Aug. 31, 2016).

${ }^{180}$ See e.g. UNCTAD, supra note 30 at 88.
} 
Related to the above, transparency and access to information is a crucial ingredient for any such policy change. In light of bureaucratic inertia, pressure for change is unlikely to come from within responsible ministries. That is why broad access to investment claim related information is needed to raise public awareness, trigger public debates and guide public choices. Current developments from broad transparency clauses in newly negotiated treaties such as the TPP to parallel efforts to enhance transparency under already existing IIAs through the Mauritius Conventions are encouraging. If ratified and widely accepted, these trends towards more transparency promise to be an effective antidote against status quo bias, path dependency and bureaucratic inertia by enhancing the impact of investment claims on the domestic policy discourse.

\section{THE IMPACT OF ARBITRATION AwARDS ON RULE MAKING}

While investment claims have had only a limited impact on treaty design, the influence of case law developments on treaty making is more pronounced. As we hypothesized in Section 1, the parallel judge-made law in arbitration may cause states to make changes in their investment treaties. In this section we begin by briefly describing how we can identify the causal influence of ISA awards and then proceed to investigating the impact of case law on procedural and substantive treaty design innovations through several case studies. Importantly, the ambition of this section is not to comprehensively map the interaction between case law and treaty making, which would require many volumes, but rather to show that investment awards, in contrast to clauses or claims, play a systematic role in shaping investment treaty design.

\section{A. Identifying the impact of arbitral case law}

Investment arbitrators exercise an implied interpretive power as part of their adjudicatory function. ${ }^{181}$ In exercising that power, tribunals can impact future treaty design in two major ways. First, arbitrators may fill gaps left open by the drafters providing a solution or "focal point" to a normative void that is later codified in subsequent investment treaties. Second, arbitrators may interpret existing provisions in a way unintended by the contracting parties prompting states to correct the perceived misinterpretation in future treaties.

How can we causally attribute a change in treaty design to a development in investment case law? Investment awards only began to spread in the early 2000s. That means that only period 4 innovations could have been caused by

${ }^{181}$ Roberts, supra note 57 at 180. 
arbitral decisions. In Table 1 in section 1, we identified both substantive and procedural changes introduced in that period. By looking at these treaty design changes in their legal context, we can investigate whether they are related to parallel developments in investment case law. ${ }^{182}$

In considering the legal context of treaty innovations, we do not need to limit our analysis to cases rendered against the country that first introduced a treaty design innovation. We instead assume that countries learn from awards rendered generally. There are several reasons for the merit of this assumption. First of all, as we discussed above, tribunals cite previous awards that are not limited to cases involving the same treaties or the same IIA. ${ }^{183}$ Hence, awards rendered against any state $\mathrm{A}, \mathrm{B}$ or $\mathrm{C}$ can affect outcomes in a case against state $\mathrm{D}$ in similar ways as a prior unrelated award against state D. Second, states are unlikely to react to a single unwanted arbitral decision by changing their future treaties, but rather react to lines of jurisprudence. It is in the ad hoc nature of investment arbitration with its changing pools of arbitrators that decisions can vary in quality, interpretation and outcome. ${ }^{184}$ When a particular arbitral decision falls short on any of these fronts (from the contracting states' perspective), the host country may file for the annulment or setting aside of the award and/or the home state may openly criticize the arbitral tribunal, as happened on occasions. ${ }^{185}$ But only if a controversial case is subsequently cited and followed by other cases so that it develops into a line of jurisprudence, which can affect the outcome of future cases, contracting states are likely to respond by taking sides in interpretive debates through their treaty making. We thus believe it is justified to look at developments in the entire body of arbitral decisions to find an impact on specific treaty design

${ }^{182}$ Indeed, this seems to be the methodology adopted in an UNCTAD study although the parts contextual arbitral disagreement and the part on treaty design changes is somewhat disjunct. See UNCTAD, supra note 4.

${ }^{183}$ See supra Section "Investment arbitration case law".

184 This in-built inconsistency is the primary reason why some scholars are skeptical about the feasibility and desirability of an investment appeal mechanism. See generally Appeals Mechanism in International Investment Disputes, (Karl P Sauvant \& Michael Chiswick-Patterson eds., 2008).

185 In 2003, for instance, Switzerland sent a letter to the ICSID Secretariat complaining about the $S G S v$ Pakistan tribunal, criticizing the narrow meaning it gave to the umbrella clause in the Switzerland-Pakistan BIT which "runs counter to the intention of Switzerland." The letter is reprinted in its relevant parts in ANDREW NEWCOMBE \& LLUíS PARADELL, LAW AND PRACTICE OF INVESTMENT TREATIES: STANDARDS OF TREATMENT 466-467 (2009); see also Gabrielle Kaufmann-Kohler, Chapter 15. Non-Disputing State Submissions in Investment Arbitration: Resurgence of Diplomatic Protection?, in Diplomatic AND Judicial Means of Dispute SETtlement 307-326, 315 (Marcelo Kohen, Laurence Boisson de Chazournes, \& Jorge E. Viñuales eds., ). 
innovations. $^{186}$

If we thus expect that states take sides in major debates on how prominent treaty norms are to be interpreted or practical procedural questions are to be resolved, then how can we tell whether a given treaty design change is caused by a development in case law and not the result of another factor? A treaty design change will be causally related to a development in case law when it cannot be explained devoid of its legal context. For example, preventing MFN from applying to dispute settlement provisions pre-supposes a legal controversy on the scope of MFN. Similarly, the clarification that the minimum standard of treatment refers to customary international law would be unnecessary but for the interpretive disagreement on the content of that provision. As we shall see through several case studies, substantive innovations can only be meaningfully explained through their case law context, while procedural changes may have been caused by other factors as well.

\section{B. Case studies of investment treaty changes induced by case law}

To assess the degree to which case law shapes treaty design we link substantive and procedural innovations to developments in investment arbitration through several case studies. We do not, however, systematically investigate what factors drive the subsequent diffusion of these innovations merely noting that such diffusion does take place.

\section{Substantive refinements}

With respect to the substantive innovations of period 4, a strong link exists between arbitral decisions and treaty design changes. In Table 1, we identified several treaty design changes that relate to the clarification of four core elements: (1) the notion of investment, (2) the scope of indirect expropriation, (3) the content of FET and (4) the reach of the MFN principle. These four elements have spread across the IIA universe with FET, expropriation and investment definition innovations existing in about every second newly concluded IIA in 2014. Through a set of case studies, we will show that each of these period 4 innovations can be linked to debates in arbitral case law. Each debate began with a controversial case and later inspired awards that

\footnotetext{
${ }^{186}$ Future research may then investigate whether this assumption holds as an empirical matter. Being involved in a case that includes a controversial interpretation may affect the propensity of a state to react to it in future treaty practice. Such research would shed light on whether states are Bayesian learners or bounded rational when it comes to digesting case law.
} 
adamantly followed or rejected the interpretation advanced therein. These lines of jurisprudence then triggered a reaction by states manifested as treaty design adjustments in newly concluded agreements.

a. Salini-Defining the notion of investment

The definition of investment has generated much interpretive quarrel. An asset must qualify as an "investment" under an IIA to benefit from the treaty's protection. For investment arbitration, the existence of an investment is a threshold requirement that must be met in order to establish a tribunal's jurisdiction ratione materiae. The concept of investment is thus central to the treaty architecture, yet it long remained vaguely defined. The ICSID Convention, under whose umbrella most investment arbitrations are conducted, simply states in Article 25(1) that the "jurisdiction of the Centre shall extend to any legal dispute arising directly out of an investment" without clarifying the term. IIAs, in turn, predominantly defined investment as "every type of asset" including, but not limited to an illustrative list of specifically mentioned assets such as movable and immovable property, shares, intellectual property rights but also claims to money or performance. Hence, the notion of investment remained vaguely defined.

As a result, divergent interpretations developed in case law to give meaning to the term and its outer limits. On one extreme, a line of cases emerged following Fedex v Venezuela (1997) and Salini v Morocco (2001) according to which a transaction has to satisfy four cumulative requirements to qualify as an investment ("Salini criteria"): (1) commitment of capital, (2) certain duration, (3) assumption of risk, and (4) a contribution to the host state's development. ${ }^{187}$ At its high point, the annulment committee in Mitchell $v$ Congo struck down an award for assuming jurisdiction when the underlying investment - an American law firm in the Democratic Republic of Congo did not contribute to the host state's development thus failing to meet the Salini criteria. ${ }^{188}$ On the other extreme, the annulment committee in Malaysian Salvors denied the existence of such investment criteria and annulled an award that had applied them. It instead held that the term investment excludes simple sale contracts, but does not have any intrinsic meaning absent a definition by the contracting or disputing parties. ${ }^{189}$

187 Fedax $v$ Venezuela, ICSID Case No. ARB/96/3, Decision on Jurisdiction (July, 11 1997), đ 43; Salini v Morocco, ICSID Case No. ARB/00/4, Decision on Jurisdiction, (July 23, 2001), ๆ 56.

188 Patrick Mitchell $v$ Democratic Republic of the Congo, ICSID Case No. ARB/99/7, Decision on the Application for Annulment of the Award (Nov. 1, 2006), ๆๆ 30-33, 48.

${ }^{189}$ Malaysian Historical Salvors, SDN, BHD v. The Government of Malaysia, ICSID Case 
To counteract the uncertainty and divergence characterizing the case law, states began clarifying the notion of investment in their treaties. The USAUruguay BIT (2005) was the first BIT to explicitly stipulate in Article 1 that "an investment means every asset ... that has the characteristics of an investment, including such characteristics as the commitment of capital or other resources, the expectation of gain or profit, or the assumption of risk." The USA-Uruguay BIT formulation includes some of the Salini criteria, but notably does not mention the contribution to host state development. At the same time, it is more restrictive than what the Malaysian Salvors annulment committee deemed to be the ICSID default rule. Hence, the clarifying language, which has since been diffused to other treaties, occupies a middle ground between the extreme positions taken in case law. ${ }^{190}$

b. Ethyl/Methanex - Drawing a line between indirect expropriation and general regulations

Early NAFTA cases gave rise to an intense legal and public debate as to whether a state has to compensate foreign investors, if by virtue of general regulatory measures part of the investor's business becomes practically worthless. The issue first arose in the case Ethyl $v$ Canada and was fully litigated in the Methanex $v$ United States dispute. ${ }^{191}$ In both instances, a province or state had passed legislation that effectively banned the use of certain gasoline additives due to health reasons and in both cases part of the business of the producers of these substances suffered losses that were claimed to be tantamount to an outright expropriation. Most investment treaties, including NAFTA, protect investors also against indirect expropriation, i.e. those measures that involve no formal taking of assets, but effectively deprive an investor of the value associated with its assets.

In its 2005 award, the Methanex tribunal resolved the case by distinguishing between expropriatory measures mandating compensation and general bona fide regulations not giving rise to compensation. ${ }^{192}$ The tribunal

No. ARB/05/10, Decision on the Application for Annulment (Apr. 16, 2009), 9थ 71-2.

${ }^{190}$ See e.g. Austria-Kazakhstan (2010), Canada-China (2012), India-Mexico (2007), JapanColumbia (2011), Japan-Peru (2008), Switzerland-Egypt (2010), Guatemala- Trinidad and Tobago (2013).

${ }^{191}$ Ethyl Corporation v The Government of Canada, UNCITRAL; Methanex Corporation v United States of America, UNCITRAL,

${ }^{192}$ Glamis Gold, Ltd. $v$ The United States of America, UNCITRAL, Final Award (June 8, 2009), \ 354; El Paso Energy International Company v Argentine Republic, ICSID Case No. ARB/03/15, Award (Oct. 31, 2011), Фף 236-240; SAUR International S.A. $v$ Argentine Republic, ICSID Case No. ARB/04/4, Decision on Jurisdiction and Liability 
stated that "as a matter of general international law, a non-discriminatory regulation for a public purpose, which is enacted in accordance with due process and, which affects, inter alios, a foreign investor or investment is not deemed expropriatory and compensable." ${ }^{\prime 93}$ The tribunal thereby effectively adopted the legal standard advanced in the U.S.' written submissions. ${ }^{194}$ Yet, absent a clear textual carve-out in the treaty, there was a risk that another arbitral tribunal would disagree with the Methanex award and not read a BIT's clause on expropriation in light of the underlying customary international rules. In response, the United States began inserting a clarifying annex to its newly concluded treaties and other countries followed suit. The USA-Uruguay BIT (2005), for instance, states in Annex B that the treaty's expropriation clause "is intended to reflect customary international law concerning the obligation of States with respect to expropriation" and that "[e]xcept in rare circumstances, non-discriminatory regulatory actions by a Party that are designed and applied to protect legitimate public welfare objectives, such as public health, safety, and the environment, do not constitute indirect expropriations."

c. Pope \& Talbot - FET as additive to the customary international law minimum standard

All early NAFTA tribunals struggled with giving meaning to NAFTA Article 1105 entitled "Minimum Standard of Treatment" which states in paragraph one that "[e]ach Party shall accord to investments of investors of another Party treatment in accordance with international law, including fair and equitable treatment and full protection and security." The Metalclad tribunal read the provision as mandating a general duty of transparency towards foreign investors. ${ }^{195}$ Considering this interpretation as an excess of power, the Supreme Court of British Columbia partially annulled the award a year later. ${ }^{196}$ The S.D. Myers v. Canada tribunal found that a tribunal should assess compliance of a state with international law generally under NAFTA Article 1105 and that a finding of violation of another international norm

(June 6, 2012), ๆ 9 396-401.

${ }^{193}$ Methanex Corporation v United States of America, UNCITRAL, Final Award (Aug. 3, 2005) Part IV, Chapter D, 17.

194 Id., U.S. Amended Statement of Defense, (Dec. 5, 2003), 1 409-413, available at: http://www.state.gov/documents/organization/27063.pdf (last visited Feb. 2, 2015).

${ }^{195}$ Metalclad Corporation $v$ The United Mexican States, ICSID Case No. ARB(AF)/97/1, Award, (Aug. 30 2000) 776.

196 United Mexican States v Metalclad Corporation, 2001 BCSC 664 (May 2, 2001), http://www.italaw.com/sites/default/files/case-documents/ita0512.pdf (last visited Feb. 2, 2015). 
would weigh heavily towards finding a breach of Article 1105. ${ }^{197}$ Most disturbing for NAFTA parties, however, seems to have been the Pope \& Talbot $v$ Canada award. Openly disagreeing with the position advanced by the United States through a NAFTA 1128 non-disputing party submission, the tribunal adopted what it called an "additive" interpretation that ascribed a protective scope to the FET clause beyond the customary international law minimum standard of treatment. ${ }^{198}$

In July 2001, the NAFTA parties reacted. Representatives of the three NAFTA states issued an authoritative interpretation through the NAFTA Free Trade Commission (FTC) pursuant to Article 1131(2) clarifying that NAFTA Article 1105 does not require a treatment above or beyond the customary international law minimum standard of treatment. ${ }^{199}$ According to Todd Weiler, the NAFTA parties thereby sought to remedy the "mistakes' which their lawyers told them were being made by the tribunals." 200 Whether or not the statement merely clarified or whether it effectively amended NAFTA is subject to an unresolved debate. ${ }^{201}$ What is clear, however, is that NAFTA parties were so convinced that this reading of fair and equitable treatment is the proper one that they integrated the explicit customary international law minimum standard references also in their subsequent treaties. Since 2002, over 40 newly concluded BITs contain explicit references linking FET to the customary international law minimum standard. ${ }^{202}$

d. Maffezini - Guarding against the application of MFN clauses to dispute settlement

One of the most controversial cases in investment law's history, Maffezini $v$ Spain, also triggered changes in treaty practice. In Maffezini, the tribunal had allowed an investor to circumvent an obligatory pre-arbitration waiting period in the Spain-Argentina BIT by using MFN to claim the more favorable treatment granted in the BIT between Spain and Chile where such a

197 S.D. Myers, Inc. v Canada, UNCITRAL, Final Merits Award (Nov. 13, 2000), ๆ甲 263-4.

198 Pope \& Talbot, Inc. v Canada, UNCITRAL Tribunal, Award on the Merits (Apr. 10, 2001), ๆ 110-117.

199 NAFTA Free Trade Commission, Notes of Interpretation of Certain Chapter 11 Provisions, sec. B (2), (July 31, 2001) available at: http://www.international.gc.ca/tradeagreements-accords-commerciaux/topics-domaines/disp-diff/NAFTAInterpr.aspx?lang=eng (last visited Feb. 2, 2015).

${ }^{200}$ Todd Weiler, Metalclad v. Mexico - A Play in Three Parts, 2 J. World Invest. 685, 704 (2001).

${ }^{201}$ Brower, supra note 58; Kaufmann-Kohler, supra note 58.

${ }^{202}$ In fact, this is not limited to the NAFTA parties. See e.g. Japan-Laos BIT (2008), Turkey-Tanzania (2011), Saint Vincent and the Grenadines-Taiwan BIT (2009). 
requirement was absent. ${ }^{203}$ Subsequent investors have followed the Maffezini strategy trying to use MFN to overcome similarly unfavorable admissibility requirements in their base treaty or to outright ground a tribunal's jurisdiction in MFN where the original treaty's consent to arbitration is too narrow. ${ }^{204}$

The Maffezini legacy produced a divide in case law and scholarship. While some tribunals have allowed investors' request to access more favorable admissibility or even jurisdictional conditions for arbitration claims, others have rejected it. ${ }^{205}$ One of the central issues in this debate has been where the presumption lies. Do states have to explicitly limit the scope of MFN to prevent circumvention of the dispute settlement architecture set up in a treaty? Or are MFN clauses subject to inherent limitations that prevent investors from accessing more favorable dispute settlement terms in third treaties? To remedy this uncertainty, several BITs have specifically circumscribed the scope of MFN clauses. The Belgium-Colombia BIT (2009), for instance, provides in Article $\mathrm{V}(3)$ " $[\mathrm{t}] \mathrm{he}$ most favourable treatment ... does not encompass mechanisms for the settlement of investment disputes, such as those contained in Articles XII and XIII of this Agreement, which are provided for in treaties or international investment agreements." Several states have followed suit. ${ }^{206}$ Most recently, such a clarification has also been introduced in the Transpacific Partnership Agreement Article 9.5(3).

\section{Procedural innovations}

What these substantive innovations had in common is that they cannot be convincingly explained devoid of their case law context. As a result, we can infer that they have been caused by debates in investment case law. The case of procedural changes introduced in period 4 is more ambivalent. On the one hand, we do see changes being driven by the same desire to correct arbitral misinterpretations that prompted the substantive innovations observed. In addition, we can also trace how arbitral decisions may have inspired the normative solutions later adopted by the treaty makers. On the other hand, the emergence and diffusion of these procedural elements is also likely to have been shaped by causal factors outside of the courtroom. The procedural

203 Emilio Agustín Maffezini v The Kingdom of Spain, ICSID Case No. ARB/97/7, Jurisdiction (Jan. 25, 2000).

${ }^{204}$ J. A. Maupin, MFN-based Jurisdiction in Investor-State Arbitration: Is There Any Hope for a Consistent Approach?, 14 J. INT. ECON. LAW 157-190 (2011).

205 Yannick Radi, The Application of the Most-Favoured-Nation Clause to the Dispute Settlement Provisions of Bilateral Investment Treaties: Domesticating the "Trojan Horse, ” 18 EUR. J. INT. LAW 757-774 (2007); Maupin, supra note 205.

${ }^{206}$ See e.g. Switzerland-Egypt BIT (2010), Japan-Colombia BIT (2011) and Japan-Iraq BIT (2010). 
innovations in period 4 have diffused albeit less successfully than their substantive counterpart.

a. Pope \& Talbot - Enhancing control mechanisms

The above-discussed substantive controversies arguably not only impacted substantive treaty design changes, but also highlighted procedural issues involving the allocation of power between arbitral tribunals and state parties.

The above-mentioned FTC interpretive note and the Pope \& Talbot tribunal is a case in point. Following the NAFTA FTC interpretation, Canada argued in Pope \& Talbot $v$ Canada that a tribunal must accept such a statement by the FTC at face value and abide by its binding force pursuant to NAFTA Article 1131(2). ${ }^{207}$ The Pope \& Talbot tribunal disagreed and proceeded to reviewing whether the statement was indeed an interpretation or rather an amendment of NAFTA. ${ }^{208}$ Although it ultimately accepted the interpretation as binding, it voiced concern about the contracting parties changing the law retroactively in an ongoing proceeding and leaned towards characterizing the statement as an amendment of NAFTA. ${ }^{209}$ The case thus raised a fundamental question of delegation - how much control do contracting states still have over the arbitral tribunals after bestowing them with adjudicatory and interpretive authority in their treaties?

Some of the procedural innovations of period 4 can be viewed as reactions to this debate. An explicit provision on preliminary objections is a form of ex ante control as it specifies the procedure in the treaty itself rather than leaving it to the party autonomy of disputants and the discretion of arbitral tribunals. A comment procedure on draft awards and the possibility to create an appeal mechanism, in turn, are forms of ex post controls, which allow contracting states to seek a correction of an arbitral misinterpretation.

At the same time, the causal connection between specific awards or debates in arbitration and procedural treaty design changes is much less clear and direct as was the case for substantive changes. The inclusion of preliminary measures can also be explained by states' desire to more easily defend against investment claims by being able to deal with frivolous claims early on in a proceeding. Similarly, commenting on draft awards and creating an appeal mechanism may not be so much about keeping a single tribunal in

\footnotetext{
${ }^{207}$ Pope \& Talbot Inc. v. The Government of Canada, UNCITRAL, Award in Respect of Damages, 31 May 2002, $₫ 22$.

${ }^{208}$ Id. ๆศ $24-47$.

${ }^{209} I d$. ๆๆ 47-51.
} 
check, but about achieving consistency and predictability in arbitration on a systemic level. Hence, while arbitral case law either through specific awards or in their totality seem to have contributed to influencing the outcomes of procedural innovations, the causal link is more tenuous as other considerations are at play as well that could have equally caused or contributed to such innovation.

b. Metalclad and Methanex - Transparency in arbitration

A second way by which arbitral decisions may have impacted procedural innovations is by serving as focal points for subsequent treaty making. In contrast to the substantive period 4 refinements, which relate to vague but existing clauses, some of the issues covered by procedural period 4 innovations were simply not dealt with in previous treaties. Consider the issue of transparency in arbitration, which regroups the period 4 innovations of amicus curiae submissions, the confidentiality of arbitral documents and the possibility of open hearings. The text of Chapter 11 provided no clear guidance on these three procedural points. ${ }^{210}$ Consequently, early NAFTA tribunals when first confronted with these issues had to find solutions on their own. These NAFTA tribunals send a message in favor of greater transparency in investment arbitration: the Metalclad tribunal allowed the publication of dispute-related information ${ }^{211}$ and the Methanex tribunal accepted amicus curiae submissions and conducted open hearings for the first time. ${ }^{212}$

Subsequent treaty practice closely followed these early arbitral decisions. In two successive statements in 2001 and 2003 the NAFTA Free Trade Commission committed the NAFTA states to making all documents relating to ISA cases public subject to redaction of confidential information ${ }^{213}$ and clarified that a tribunal is allowed to accept amicus curiae submissions. ${ }^{214}$ In

${ }^{210}$ Jack J. Jr Coe, Transparency in the Resolution of Investor-State Disputes - Adoption, Adaptation, and NAFTA Leadership, 54 UnIV. KANS. LAW REV. 1339, 1364-1365 (2005). See also OECD, Transparency and Third Party Participation in Investor-State Dispute Settlement Procedures, OECD WORKING PAPERS ON INTERNATIONAL INVESTMENT (2005/01).

${ }^{211}$ Metalclad Corporation v. The United Mexican States, ICSID Case No. ARB(AF)/97/1, Decision on a Request by the Respondent for an Order Prohibiting the Claimant from Revealing Information (Oct. 27, 1997).

${ }^{212}$ Methanex Corporation v. United States of America, UNCITRAL, Decision of the Tribunal on Petitions from Third Persons to Intervene as "amici curiae" (Jan. 15, 2001). The hearings were opened through live broadcasts.

${ }^{213}$ See note 199 , sec. 1 b).

${ }^{214}$ NAFTA Free Trade Commission, Statement of the Free Trade Commission on nondisputing party participation, 7 Oct 2003, available at: www.state.gov/documents/organization/38791.pdf. 
its post-2004 treaties, Canada and the U.S. then regulated the admission of third party interventions, publication of documents and open hearings explicitly, incorporating the lessons learned from NAFTA. ${ }^{215}$

It is thus tempting to view these NAFTA earlier decisions as creating "focal points" that caused subsequent treaty makers to endorse the tribunals" view in their subsequent practice. Yet a range of causal factors seems to have been at play making it difficult to identify the magnitude of the impact of these early arbitral decisions. First of all, accompanying the discussions inside the courtroom were debates outside of it as public interest groups and critics of Chapter 11 campaigned against the "secrecy" of NAFTA tribunals putting pressure on NAFTA states to ensure greater transparency in adjudication. ${ }^{216}$

Second, disagreement among the NAFTA parties was also a major factor long impeding innovation. Already in NAFTA negotiations, Mexico had resisted to provide for a clause allowing the publication of awards, while Canada and the United States agreed to it in Annex 1137.4 of NAFTA. Mexico also fought against the publication of arbitration-related information in Metalclad ${ }^{217}$ and intervened in Methanex as non-disputing parties arguing against a tribunals' capacity to receive amicus submissions, ${ }^{218}$ while both Canada and the United States favored greater transparency. Step-by-step, Mexico then changed its position. It first agreed to the publications of documents and amicus submissions in the two FTC notes mentioned above and in 2004 it joined an earlier statement by the U.S. and Canada to open hearings in arbitration disputes. ${ }^{219}$ Whether this change of heart was induced by the transparency-favoring arbitral decisions, or was due to pressure from its NAFTA partners or domestic constituencies is unclear.

\footnotetext{
${ }^{215}$ Levesque, supra note 156.

${ }^{216}$ Kinnear and Hansen, supra note 130 at 106-109. See e.g. Ralph Nader and Lori Wallach, 'GATT, NAFTA, and the subversion of the democratic process' (2001) http://www.thirdworldtraveler.com/WTO_MAI/WTO_CAGE.html

${ }^{217}$ See supra note 211.

${ }^{218}$ Methanex Corp. v. United States, UNCITRAL, Submission of Mexico Re Petitions for Amicus Status (Nov. 22, 2000) 16.

219 See statement by the U.S. Trade Representative available at: http://www.ustr.gov/archive/assets/Trade_Agreements/Regional/NAFTA/asset_upload_fi le143_3602.pdf and statement by the Canadian government available at http://www.international.gc.ca/trade-agreements-accords-commerciaux/agr-acc/naftaalena/open-hearing.aspx?lang=en (last visited May 3, 2014). NAFTA Free Trade Commission Joint Statement, A Decade of Achievement, 16 July 2004, available at http://www.ustr.gov/archive/Document Library/Press Releases/2004/July/NAFTA Free Trade Commission Joint Statement - A Decade of Achievement.html (last visited May 3, 2014).
} 
Hence, the causal impact of early arbitral decision on transparency innovations is uncertain. On the one hand, they are likely to have facilitated the transition towards more transparency in arbitration and may even have furnished "focal points" for the states to deal with the issue in subsequent treaties. On the other hand, other factors outside of the courtroom shaped the countries' position on the issue as well, which makes it difficult to ascertain the effect induced by arbitral decisions alone.

\section{Conclusion}

This section has shown that investment case law has a systematic impact on investment treaty design. The innovation and diffusion of substantive treaty design features can be linked to specific normative debates in case law. What these substantive changes have in common is that they strive to refine treaty standards rather than reinventing them. They often take the guise of explanatory footnotes or annexes to avoid the impression that they deviate from prior treaty practice. Their tenor is thus that the original treaty content has not been altered, but merely clarified by correcting arbitral misinterpretation. Similarly, procedural innovations can often be associated with developments in case law, although a causal connection is more difficult to establish since a number of factors may be responsible for the procedural changes observed. Nevertheless, of the three factors - clauses, claims and cases - considered, investment case law seems to have the most significant effect on treaty design.

\section{CONCLUSION}

Contributing to the burgeoning computational analysis of international investment law, this article has used state-of-the-art information extraction techniques to empirically investigate the effects of investor-state arbitration on treaty design. It has shown that the impact of arbitration on investment rule making is surprisingly small. Both investment clauses and investment claims do not systematically trigger material changes in IIA design. In contrast, arbitral case law does exert a traceable influence on investment treaties. States thus behave somewhat counter-intuitively: they do not adjust their agreements in light of major legal events like the inclusion of investment clauses starting in the 1960s or their widespread use in practice from the late 1990s onwards, yet they are shaken by small and technical developments in investment arbitration to which they feel compelled to respond.

There is logic to this apparent paradox. This logic has less to do with the magnitude of extraneous changes in investment arbitration and more with the 
lawyers observing, digesting and reacting to them in national ministries. As this research suggests, investment lawyers cherish the path-dependent predictability of tried and tested legal language. Such predictability is more at risk from being unhinged by a growth of conflicting interpretations in arbitral case law, then by a new enforcement route of investment obligations or the fact that investment claims have been launched pursuant to a treaty. That is why we see countries like Germany continuing business as usual in the face of investment claims or countries like the U.S., Canada or Japan entrenching and refining their treaty design based on pre-arbitration templates rather than rethinking their agreements from scratch.

For researchers, this means that in order to explain treaty design changes, they have to take account of the variety of cognitive, social and political factors impacting investment treaty making. This article has highlighted that bureaucratic inertia, symmetry in underlying investment relations or public awareness are often more decisive for the absence or presence of legal innovation and diffusion than the raw developments in investment arbitration. The article has also shown that a mixed method approach combining computational, quantitative and qualitative analyses is particularly suitable to disentangle these different factors empirically.

For investment arbitrators, this study suggests that a state rather an investor-centric readings of substantive investment provisions is warranted. Empirically, investor-state arbitration is a mere procedural add-on that leaves the treaties' protective obligations untouched. IIAs are thus not like contracts for the benefits of third parties and should not be read as such. Instead, they are inter-state promises that sometimes can and sometimes cannot be enforced through ISA. Since their enforcement route exists independently of the rest of the treaty, we should not let it overshadow the reading of substantive treaty standards and instead treat IIAs more like all other public international treaties.

Finally, for investment stakeholders, this research suggests that they should be more concerned about states not changing their treaties when change is needed than about investment lawyers overreacting in response to developments in arbitration. While more radical change may be on the horizon, thus far we have primarily seen a reproduction and entrenchment of what is essentially a pre-ISA architecture. We thus need more rather than less reaction to investment arbitration. At the same time, careful reflection on what investment treaties are to achieve in today's world has to precede any change in treaty design so to guide our judgment as to where we need to depart from and where we need to continue with established practice. 


\section{ANNEX}

\section{A. Coding procedure}

Using international investment law textbook and treaties, we identified 55 treaty features relating to investment protection, public policy exceptions and clarifications, and ex ante and ex post controls of contracting states over the arbitration process. The list of features is detailed in the table below. For each of these 55 treaty features selected, we identified key words uniquely associated with each feature (e.g. key word "expropriat" denoting the concept of "expropriation") carefully accounting for variation in a clause's wording.

For example, one of the most important clauses in investment treaties is the "fair and equitable treatment" standard. Some treaties, however, refer to "equitable and reasonable treatment" instead. The Parkerings $v$ Lithuania tribunal held that both terms are to be understood synonymously. ${ }^{220}$ Since similar variations can be observed for virtually all features investigated, we compiled a list of possible variations per treaty feature. To verify the quality of the key word approach, we went through rounds of coding and verification of results to gradually improve precision (accounting for false positives) and recall (accounting for false negatives). The considerable uniformity of investment treaty language helped significantly to keep the list of key words per feature low. In total, our dictionary comprises over 200 key words and phrases for the 55 treaty features investigated.

This dictionary of key terms is subsequently automatically run through the dataset of IIAs using the programming language Python. If a given element from the dictionary of terms appears in a treaty, it is coded as 1 and 0 otherwise. For FTAs, only investment chapters are analyzed. Where a detailed comparison of two FTAs was required e.g. in Section 3 comparing Australian FTAs before and after the policy decision to exclude ISA, we manually also checked the financial service and exception chapters to ensure accuracy.

\footnotetext{
220 Parkerings-Compagniet AS v. Republic of Lithuania, ICSID Case No. ARB/05/8, Award (Sept., 11 2007), ๆ 198.
} 


\begin{tabular}{l|l}
\multicolumn{1}{c}{ Category } & \multicolumn{1}{c}{ Sub-category } \\
\hline Arbitration & Amicus Curiae \\
\hline Arbitration & Appellate Mechanism \\
\hline Arbitration & Arbitrator Code of Conduct \\
\hline Arbitration & Authoritative Interpretation \\
\hline Arbitration & Closed List of Remedies \\
\hline Arbitration & Comment on draft award \\
\hline Arbitration & Commission \\
\hline Arbitration & Consolidation \\
\hline Arbitration & Existence of ISA \\
\hline Arbitration & Limitation Periods for Claims \\
\hline Arbitration & Loss or Damage \\
\hline Arbitration & Notice of Intent \\
\hline Arbitration & Preliminary Objections \\
\hline Arbitration & Renvoi to State Parties \\
\hline Arbitration & State-party Participation \\
\hline Arbitration & Transparency of Proceedings \\
\hline Arbitration & Waiver of Other Proceedings \\
\hline Exception & Balance of Payments \\
\hline Exception & Bona Fide Taking Carve-out \\
\hline Exception & Compulsory License Carve-out \\
\hline Exception & Creditor Protection \\
\hline Exception & Culture \\
\hline Exception & Denial of Benefits \\
\hline Exception & Environmental Measures Clause \\
\hline Exception & Exchange Rate Measures Carve-out \\
\hline Exception & FET linked to CIL \\
\hline Exception & GATT XX \\
\hline Exception & Health Exception \\
\hline Exception & Indirect Expropriation \\
\hline Exception & Indirect FET Breach Carve-out \\
\hline Exception & International Security Exception \\
\hline Exception & Investment Characteristics \\
\hline Exception & MFN Non-application to ISA \\
\hline Exception & Minorities \\
\hline Exception & Non-conforming Measures \\
\hline Exception & Procurement Carve-out \\
\hline Exception & Prudential Measures Carve-out \\
\hline Exception & Regional Economic Integration Org. \\
\hline Exception & Security Exception \\
\hline &
\end{tabular}




\begin{tabular}{l|l} 
Exception & Subsidies Carve-out \\
\hline Protection & Access to Courts \\
\hline Protection & Arbitrary Measures Prohibition \\
\hline Protection & Compensation for Losses \\
\hline Protection & Denial of Justice \\
\hline Protection & Effective Means \\
\hline Protection & Expropriation \\
\hline Protection & Fair and Equitable Treatment \\
\hline Protection & Full Protection and Security \\
\hline Protection & Liberalization \\
\hline Protection & Non-Discrimination \\
\hline Protection & Performance Requirements \\
\hline Protection & Sojourn of Personnel \\
\hline Protection & Transfer of Funds \\
\hline Protection & Transparency of Local Laws \\
\hline Protection & Umbrella Clause
\end{tabular}

